\title{
Disclosure and Production in Sexual Violence CASES: SituATING STINCHCOMBE
}

\author{
JENNIFER KOSHAN
}

This article examines the issue of disclosure and the legacy of Stinchcombe through a review of the history of disclosure and production in criminal sexual assault proceedings and an analysis of judicial decisions and legislative enactments in this context. The author presents a feminist analysis of the tension between those representing the rights of accused persons who seek 10 access a complainant's personal records and the voices of equality-seeking and anti-violence groups that challenge stereotypes about sexual violence against women. The author presents a comprehensive review of the lower court decisions in production applications since the Supreme Court of Canada decision in R. v. Mills. The author concludes that while Bill C-46 and Mills are positive developments, a great deal of discretion is left to trial judges to decide on the merits of production on a case-by-case basis, and such decisions are granted much deference by appellate courts. The exercise of discretion may encourage the application of stereotypes about women and sexual violence and is the reason an absolute ban on production is preferred by women's and antiviolence groups.
L'auteur de l'article examine la question de la divulgation et de l'incidence de l'affaire Stinchcombe au moyen de l'étude de l'histoire de la divulgation, de la comparution dans les procès d'agression sexuelle criminelle et de l'analyse de la jurisprudence et de la législation dans ce contexte. L'auteur présente une analyse féministe de la tension qui existe entre les représentants des droits des accusés qui cherchent $\dot{a}$ avoir accès aux dossiers personnels du plaignant et les groupes revendiquant l'égalité et la lutte contre la violence qui s'objectent aux stéréotypes sur la violence sexuelle contre les femmes. L'auteur revoit l'ensemble des décisions du tribunal inférieur relatives aux demandes de comparution depuis la décision de la Cour suprème du Canada dans l'affaire R. c. Mills. L'auteur en arrive a la conclusion que malgré le projet de loi C-46 et la décision Mills qui représentent des développements positifs. les juges disposent de beaucoup de discrétion pour décider - au cas par cas - des mérites de la comparution. De plus, les cours d'appel accueillent ce genre de décision avec beaucoup d'égards. Ce recours à la discrétion peut encourager les stéréotypes à lëgard des femmes et de la violence sexuelle, et c'est pour cette raison que les organisations féminines et de lutte contre la violence demandent qu'elle soit formellement interdite.

\section{TABLE OF CONTENTS}

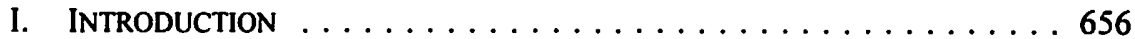

II. Production AND PRIVILEge:

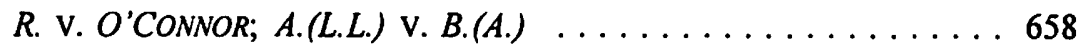

III. POST-O'CONNOR DEVELOPMENTS:

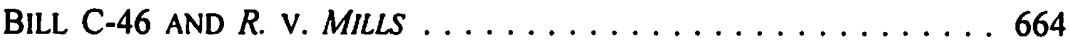

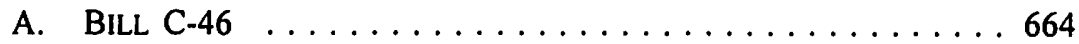

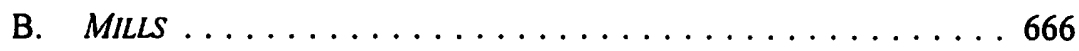

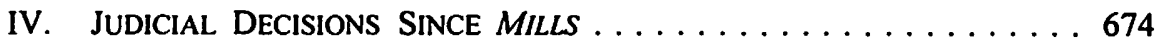

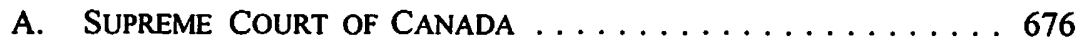

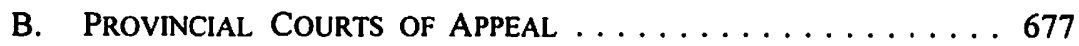

C. LowER Courts $\ldots \ldots \ldots \ldots \ldots \ldots \ldots \ldots \ldots \ldots \ldots \ldots$

Assistant Professor, Faculty of Law, University of Calgary. The author wishes to thank Glen Luther and Sheilah Martin for their helpful comments on earlier drafts of this article, and James Pickard and Jennifer Francis for their excellent research assistance. 
V. Other Production ISSUES $\ldots \ldots \ldots \ldots \ldots \ldots \ldots \ldots \ldots \ldots 65$

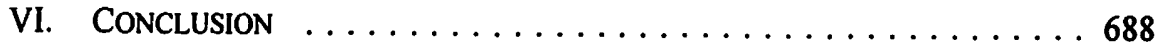

Since 1991, complainants' access to justice following sexual violation has been conditioned on a second coerced violation of their person and privacy: legalized access to their entire lives.'

Generally, if you destroy the complainant in a prosecution, ... you destroy the head. You cut off the head of the Crown's case and the case is dead.... [T] he defence really now is slice and dice time for the complainant. ${ }^{2}$

\section{INTRODUCTION}

For people working on issues relating to violence against women and children, a discussion of disclosure cannot take place in the abstract. In this context, the saga of disclosure has been one of responding to new defence strategies, and seeking to expose the underlying myths and stereotypes about women and violence which have permeated sexual assault cases for some time. This article situates the issue of disclosure and the legacy of Stinchcombe in the context of sexual violence against women and children. I will review the history of disclosure and production in criminal sexual assault proceedings, analyze judicial decisions and legislative enactments in this context, and identify unaddressed issues.

A feminist analysis of a criminal law issue should begin with an acknowledgment of the biases inherent in the criminal justice system. Academic analyses and judicial decisions expose the fact that disadvantaged men, for example men of colour ${ }^{3}$ and Aboriginal men, ${ }^{4}$ may experience bias in the investigation, prosecution, hearing, and sentencing of criminal offences. It is important to acknowledge that non-disclosure has played a role in the wrongful conviction of disadvantaged men in the past, ${ }^{5}$ although there are no sexual assault cases where a claim of wrongful conviction based on a lack of disclosure or production has been successfully made. It must also be acknowledged that men are sometimes victims of sexual violence, although rarely at the hands of

1 Women's Legal Education and Action Fund, Submissions to Standing Commillee on Justice and Legal Affairs Review of Bill C-46, March 1997.

: Defence lawyer Michael Edelson, as quoted by C. Schmitz, “'Whack' sexual assault complainant at preliminary inquiry" The Lawyers Weekly (27 May 1988) 22 at 22.

3 C. Aylward, Canadian Critical Race Theory: Racism and the Law (Halifax: Fernwood Publishing, 1999) cites $R$. v. Parks (1993), 15 O.R. (3d) 324 (C.A.), 84 C.C.C. (3d) 353 and R.D.S. v. The Queen, [1997] 3 S.C.R. 484, 151 D.L.R. (4th) 193 as examples.

- For a relatively recent example see Royal Commission on Aboriginal Peoples, Bridging the Cultural Divide: A Report on Aboriginal People and Criminal Justice in Canada (Ottawa: Communication Group, 1996). For a useful listing of the numerous academic studies, government reports and public inquiries in this area in the 1980 s, see P.A. Monture-Okanee \& M.E. Turpel, "Aboriginal Peoples and Canadian Criminal Law: Rethinking Justice" (1992) U.B.C. L. Rev. 239 at 259-61.

$3 \quad$ See, e.g., Nova Scotia, Findings and Recommendations of the Royal Commission on the Donald Marshall, Jr., Prosecution (Halifax: The Commission, 1989). Sopinka J. cited the Marshall case in Stinchcombe as an example of the importance of Crown disclosure in preventing miscarriages of justice (infra note 14 at 336). 
women. ${ }^{6}$ For feminists, the point of engagement with disclosure and production issues has been to ensure that the fact-finding process is free from myths and stereotypes regarding women, children and sexual violence.

Violence against women and children occurs at alarming rates in Canadian society. According to the 1993 Statistics Canada Violence Against Women Survey, 39 percent of all women have experienced at least one incident of sexual assault since the age of 16 , and over half of these women have experienced more than one such incident. Women with disabilities, women living in poverty, lesbians, immigrant and refugee women, women of colour, Aboriginal women, sex-trade workers, young women and children are often more vulnerable to, and specifically targeted for sexual violence, and men are the overwhelming perpetrators. ${ }^{7}$ Despite decades of work by anti-violence activists, violence against women remains a reflection and reproduction of inequality in our society. ${ }^{8}$ Moreover, while women have long sought the protection of the law in response to sexual violence, they have often been revictimized by a system that places little value on the place of the victim and has been characterized by discriminatory attitudes, practices, and laws. ${ }^{9}$ For this reason amongst others, sexual violence continues to be one of the most under-reported crimes in Canada. ${ }^{10}$ As defence practices, disclosure and production must be considered within the broader context of systemic discrimination against survivors of sexual violence.

Since the late 1970s there has been a tremendous amount of legislative and judicial reform to the law of sexual assault. While the Supreme Court of Canada has noted the "dialogue" between the courts and legislatures in this regard," the voices of equality seeking and anti-violence groups, as well as those representing the rights of accused persons, have played an essential role in this conversation. ${ }^{12}$ In the context of disclosure and production, the conversation arguably began once more rigorous "rape shield" laws made it difficult for defence lawyers to challenge complainants through questions about their sexual past and sexual reputation. Defence counsel initiated this

Canadian Research Institute on the Advancement of Women, Factsheet on Violence Against Women and Girls (Ottawa: CRIAW, 2000) [hereinafter Factsheet on Violence Against Women], citing (1999) 18:9 Juristat 9 , where it is reported that only 6 percent of all violent crime involves girls or women against men or boys. Statistics Canada, "The Violence Against Women Survey" The Daily (18 November 1993) as cited in Factsheet on Violence Against Women, ibid; The Law Society of British Columbia, Gender Equality in the Justice System: A Report of the Law Society of British Columbia Gender Bias Committee vol. 2 (Vancouver: Law Society of British Columbia, 1992), c. 7 [hereinafter Gender Equality].

* S. Martin, "Some Constitutional Considerations on Sexual Violence Against Women" (1994) 32 Alta. L. Rev. 535 at 550-51.

4 See, e.g., Gender Equality, supra note 7 at 7-72 to 7-98.

$10 \quad$ Factsheet on Violence Against Women, supra note 6.

"R. v. Mills, [1999] 3 S.C.R. 668 at paras. 20, 57 [hereinafter Mills].

12 Elizabeth Sheehy argues that "All of the legislation and policy that recognizes women's rights to be free of male violence has been put in place because of the political strength and persistence of the women's movement in our country." See E. Sheehy, "Legal Responses to Violence Against Women in Canada" (1999) 19 Can. Woman Stud. 62. See also S. Mclntyre, "Redefining Reformism: The Consultations That Shaped Bill C-49" in J.V. Roberts \& R.M. Mohr, eds., Confronting Sexual Assault: A Decade of Legal and Social Change (Toronto: University of Toronto Press, 1994) 293. 
conversation by adopting a new strategy for testing credibility in sexual assault cases - seeking access to complainants' personal records. ${ }^{13}$

\section{Production and Privilege: $R$. v. O'Connor; $A$.(L.L.) v. B.(A.)}

It is important to distinguish the practice of applications for third-party records from disclosure as sought in the Stinchcombe case, which involved actual witness statements in the possession of the Crown. ${ }^{14}$ In sexual assault cases, counsel were not content with the fruits of applications for Crown disclosure, and sought records relating to the complainant in the hands of third parties. Records relating to every conceivable aspect of complainants' lives were sought, including counselling, child welfare, adoption, drug and alcohol treatment, residential schooling, abortion and birth control clinic, and social welfare records, as well as personal diaries, family correspondence, and records from prison, employment, and immigration. ${ }^{15}$ This strategy was not employed to the same degree outside the sexual assault context and was not foreseen by the Supreme Court in Stinchcombe. As stated by Sopinka J. in Stinchcombe, "I am confident that disputes over disclosure will arise infrequently when it is made clear that counsel for the Crown is under a general duty to disclose all relevant information." ${ }^{16}$ Disputes over disclosure subsequently took on a new form, involving not only the Crown and defence, but also complainants and third-party record holders.

Applications for third-party records became routine rather than unique in sexual assault cases throughout the $1990 \mathrm{~s}^{17}$ Lower courts were inconsistent in dealing with the plethora of applications, and eventually the issue came before the Supreme Court in $R$. v. $O^{\prime}$ Connor, in which a bishop and former principal of a residential school in Williams Lake, B.C. was charged with several sexual offences against four of his former students and employees. At trial, O'Connor sought an order that the Crown obtain and disclose the complainants' medical, counselling, school, and employment records. This order was made without notice to the complainants or record holders. Later, the defence sought further disclosure, including the diary of one of the complainants. When the Crown was not forthcoming with certain aspects of the disclosure order, the defence was granted a stay of proceedings. ${ }^{18}$

At the Court of Appeal the stay was overturned and the matter was sent back to trial..$^{19}$ In a second decision, the Court of Appeal dealt with the issue of records, developing guidelines for production that were subsequently considered by the Supreme Court of Canada. The Court of Appeal set out a two-stage procedure for production of third-party records:

K. Busby, "Discriminatory Uses of Personal Records in Sexual Violence Cases" (1997) 9 C.J.W.L. 148 at 148, 151 [hereinafter Busby (1997)]. Busby argues at 148 that other factors supporting this new strategy included the Stinchcombe case. as well as "the growing public and judicial interest in "false memory syndrome."

is R. v. Stinchcombe, [1991] 3 S.C.R. 326 [hereinafter Stinchcombe].

is See Busby (1997), supra note 13 at 149-50.

16. Stinchcombe, supra note 14 at 340-41 [emphasis in original].

17 This was recognized by the majority in Mills, supra note 11 at para. 113.

18 (1992), 18 C.R. (4th) 98 (B.C. S.C.).

1.) (1994). 89 C.C.C. (3d) 109 (B.C. C.A.). 
At the first stage, the applicant must show that the information contained in the medical records is likely to be relevant either to an issue in the proceeding or to the competence of the witness to testify. If the applicant meets this test, then the documents meeting that description must be disclosed to the court.

The second stage involves the court reviewing the documents to determine which of them are material to the defence, in the sense that, without them, the accused's ability to make full answer and defence would be adversely affected. If the court is satisfied that any of the documents fall into this category, then they should be disclosed to the parties, subject to such conditions as the court deems fit. ${ }^{20}$

Several intervenors made submissions when $O^{\prime}$ Connor was heard by the Supreme Court. ${ }^{21}$ A coalition comprised of the Aboriginal Women's Council, DAWN Canada, the Canadian Association of Sexual Assault Centres, and LEAF argued that personal records should never be made available to the accused in criminal sexual assault proceedings. The coalition's argument was based on several points. First, personal records were said to be irrelevant, or very rarely relevant, to the issues in a criminal sexual assault trial. Arguments supporting relevancy were said to be based on myths and stereotypes about women, children, and sexual assault, including the "foundational myth" that "women are uniquely prone to lie about rape and to fabricate rape charges that place innocent men at risk."22 The coalition also argued that disclosure may have the effect of deterring women from reporting sexual offences to the police or from seeking counselling, where they fear an invasion of their privacy and equality at trial. The coalition noted the adverse impact of disclosure on certain groups of women and children who are more vulnerable to sexual assault and more vulnerable to having records made about them: those with disabilities, those who are Aboriginal, those who are racialized, and those who are poor. The coalition's position in $O^{\prime}$ Connor was summarized as follows:

[U]ntil the devaluation of women and children, their word, and their integrity are addressed instead of reinforced by law, this Court should hold that disclosure of complainants' personal records is so likely to reinstate sexism in the administration of criminal law, to deter reporting, to distort the fact finding process and to violate victims' integrity that affirmation of complainants' constitutional rights, no less than of the integrity of the justice system, requires that no personal records be disclosed in any sexual offence proceeding. ${ }^{23}$

No intervenors represented the rights of the accused in $O^{\prime}$ Connor, but in a case heard by the Supreme Court at the same time, A.(L.L) v. B.(A.), the Criminal Lawyers' Association argued that Stinchcombe should apply to records in the hands of third

(1994), 90 C.C.C. (3d) 257 at 261 (B.C. C.A.).

[1995] 4 S.C.R. 411 [hereinafter $O^{\prime}$ Connor]. Intervenors included the Canadian Mental Health Association, the Canadian Foundation for Children, Youth and the Law, and the Attorneys General of Ontario and Canada.

$O$ 'Connor, ibid. (Intervenor's Factum at para. 30). The coalition notes that "only the most transparently groundless rape myths" were discredited in $R$. v. Seaboyer; $R$. v. Gayme, [1991] 2 S.C.R. 577 [hereinafter Seaboyer].

$O{ }^{\prime}$ Connor, ibid. at para. 65 . 
parties, such that all "potentially relevant" personal records should be disclosed to the accused. ${ }^{24}$

In late 1995 the Supreme Court handed down its decisions in $O^{\prime}$ Connor and A.(L.L.). In $O^{\prime}$ Connor, a majority of the Court upheld the decision overturning the stay of proceedings on the basis that the non-disclosure in the case had not violated O'Connor's right to full answer and defence. A differently constituted majority built on the Court of Appeal's two-step procedure for disposing of applications for third-party records. The majority held that where the accused could satisfy a judge that the third-party records were "likely relevant" or had a reasonable possibility of being logically probative to an issue at trial or the competence of a witness to testify, the records were to be produced to the trial judge..$^{25}$ At the second stage of the application, the trial judge was to review the records and evaluate several factors to determine whether the evidentiary value of the records outweighed their negative effects, in which case the records were to be produced to the accused. The factors to be used in making this determination included the extent to which the records were necessary for the accused to make full answer and defence, the probative value of the records, the reasonable expectation of privacy associated with the records, whether production would be premised upon discriminatory beliefs or biases, and the potential prejudice that production would bring to the complainant's dignity, privacy, or security of the person. A majority of the Court rejected two other factors set out in the judgment of the minority: "the extent to which production of records of this nature would frustrate society's interest in encouraging the reporting of sexual offences and the acquisition of treatment by victims," as this matter was seen as better dealt with by procedural means, and "the effect on the integrity of the trial process of producing, or failing to produce, the record," as this matter was seen to be more germane to the question of admissibility. ${ }^{26}$

The majority noted that its approach marked a departure from Stinchcombe, where the onus to support non-disclosure was on the Crown, and the test of likely relevance

A.(L.L.) v. B.(A.), [1995] 4 S.C.R. 536 at para. 16 [hereinafter A.(L.L.)]. This argument was also made by the respondent, B.(A.). Other intervenors in the case were the Canadian Foundation for Children, Youth and the Law, the coalition from $O^{\prime}$ Connor, and the Attorneys General of Canada and Manitoba.

A point of terminology: "disclosure" has traditionally been used to refer to the procedure when records in the hands of the Crown are turned over to the defence, as in Stinchcombe, supra note 14. In $O^{\prime}$ Connor the term "production" is used to refer to the procedure when personal records in the hands of third parties, most often relating to the complainant, are tumed over to the defence. Another usage has developed, where "production" describes the first stage where third-party records are provided to a judge for a review of whether they should be seen by the defence, while "disclosure" describes the second stage where records are handed over to the defence. See, e.g., K. Busby, "Third Party Records Since R. v. O'Connor" (2000) 27 Man. L.J. 355 [hereinafter Busby (2000)]. To make matters more complicated, Mills, supra note 11 at para. 53, adopts the opposite usage: "disclosure" to the judge and "production" to the accused. The terms are commonly used interchangeably in the context of third-party records, although the Criminal Code refers only to "production," even for records in the hands of the Crown. Arguably, the term "production" is more sterile, and sounds less invasive than "disclosure." While I prefer the latter term for this reason, to avoid confusion I will use the term "production" when referring to personal records in the hands of third parties, and "disclosure" when referring to records in the hands of the Crown. 
was a question of usefulness of the material to the defence. The majority justified its approach in $O^{\prime}$ Connor on the basis that the records were not in the possession of the state, and "third parties have no obligation to assist the defence." 27 While the relevance threshold for production was higher than that for disclosure in Stinchcombe, the majority emphasized that it was a low rather than an onerous burden upon the accused. ${ }^{28}$ In response to the minority's skepticism that third-party records would be relevant very often, the majority pointed to the fact that such records had been ordered produced in many previous cases, thereby supporting their relevance. ${ }^{29}$

The majority of the Court also gave several problematic examples of situations where they believed personal records would meet the test of likely relevance - where the records concerned the "unfolding of events," the credibility of the complainant, or "the use of a therapy which influenced the complainant's memory of the alleged events." 30 While this dicta has been offset to some extent by amendments to the Criminal Code following $O^{\prime}$ Connor, the likely relevance of evidence pointing to counsellors' influence over their clients' memories continues to be assumed in production applications, as will be shown in my analysis of recent cases. ${ }^{31}$

Although this issue did not arise on the facts of the case, a majority of the Court in $O$ 'Connor also dealt with Crown disclosure of personal records relating to the complainant. ${ }^{32}$ Where the Crown was in possession of such records, the majority held that they were to be disclosed according to Stinchcombe, regardless of their private and confidential nature. According to the majority, personal records in the possession of the Crown must be assumed to be relevant, and to have been subject to a waiver of confidentiality, such that the privacy interests in the records did not have to be balanced against the accused's right to make full answer and defence. ${ }^{33}$ As in Stinchcombe, it would still be open to the Crown to prove that the records were clearly irrelevant or privileged. Failing this, personal records in the possession of the Crown were to be disclosed to the defence.

A concurring judgment in $O^{\prime}$ Connor was written by L'Heureux-Dubé J., in which four members of the Court agreed with the notion of a two-step procedure for production applications but disagreed as to the factors to be applied and at what stages of the process. Unlike the majority, the minority recognized the equality rights at play in this context:

29 Ibid. at para. 27. The minority strongly disagreed with this reasoning at para. 145 .

3o Ibid. at para. 29. Busby (1997), supra note 13 critiques this aspect of the case at 158-66.

"See below, Part IV.

32 The dissenting justices in $O^{\prime}$ Connor, supra note 21 at para. 98, did not deal with the issue of Crown disclosure and the extent to which the complainant's interests must be balanced with those of the accused in this context, finding that any such discussion would be "strictly obiter." Busby (1997), supra note 13 at 154, notes that "none of the parties or intervenors made submissions on this point." 
It is a common phenomenon in this day and age for one who has been sexually victimized to seek counselling or therapy in relation to this occurrence. It therefore stands to reason that disclosure rules or practices which make mental health or medical records routinely accessible in sexual offence proceedings will have disproportionately invasive consequences for women, particularly those with disabilities, and children. In particular, in determining questions of disclosure of records of persons allegedly assaulted in institutions where they get psychiatric assistance, the courts must take care not to create a class of vulnerable victims who have to choose between accusing their attackers and maintaining the confidentiality of their records. ${ }^{34}$

As for the two-step procedure for production, the minority justices held that at the first stage, in addition to the accused establishing likely relevance, the trial judge should balance the salutary and deleterious effects of production to the court, considering the rights of the accused to full answer and defence, and of the complainant to privacy and equality. ${ }^{35}$ Moreover, establishing likely relevance was said to be a significant burden for the accused. ${ }^{36}$

The majority decision on production and disclosure in $O^{\prime}$ Connor was criticized by several commentators. It was argued that the case was "disastrous for women and children who have been sexually violated and those who work with them," ${ }^{13}$ and that it failed to acknowledge the equality rights of complainants, though these had been put forward by the Attorneys General of Ontario and Canada, and the intervenor coalition. ${ }^{38}$ Many called for legislative action after $O^{\prime}$ Connor, leading to Bill C-46, discussed below. ${ }^{39}$

Another important aspect of the production issue relates to whether complainants and third parties have standing to challenge applications for production. Traditionally, complainants have not had standing in criminal trials, as they are considered "third parties" with no legal interest in the outcome of the case. A companion case to $O^{\prime} C o n n o r, A .(L . L$.$) , set out the important principle that complainants and third-party$ record holders have standing to make submissions in production applications and to appeal the outcome of such interlocutory applications. ${ }^{40}$ This ruling is significant for

A.(L.L.), supra note 24 at paras. 24-28, following the Court's earlier decision in Dagenais v. Canadian Broadcasting Corp., [1994] 3 S.C.R. 835. The procedure to be followed by the third party seeking to appeal the interlocutory order depends upon the level of court at which the order was granted. Interlocutory decisions of a provincial court are challengeable by an application for 
its recognition that third parties affected by judicial decisions must have an opportunity to be heard, as this amounts to a reconceptualization of the role of complainants and third parties in criminal cases. Moreover, it sets the stage for the rights balancing approach later taken by the Supreme Court in Mills. ${ }^{41}$

The minority in $A$.(L.L.) also dealt with whether counselling records should be subject to a class privilege, as argued by the complainant, the record holders, and some intervenors, including the coalition involved in $O^{\prime}$ Connor. Class privilege creates a prima facie presumption that the communications at issue are "inadmissible or not subject to disclosure" unless the party seeking disclosure can prove that "an overriding interest commands disclosure." ${ }^{42}$ Writing for the minority, L'Heureux Dubé J. held that the doctrine of privilege should not be extended to the counsellor-client relationship as a class. ${ }^{43}$ The minority rejected the American approach where statutory privilege has been enacted by several states, creating an absolute privilege for communications between counsellors and sexual assault complainants in criminal trials. ${ }^{44} \mathrm{An}$ important consideration for the minority was the diverse class of actors involved - counsellors may be medical professionals, pastors, parents, sexual-assault centre workers, and so on, as compared with the relatively well-defined classes to which privilege was currently available - solicitor-client, informer, and spousal relationships. For the minority, it was preferable to determine privilege on a case-by-case basis, where it would be granted if the "Wigmore criteria" were met." It was said that this inquiry would likely turn on a "balancing of the relative values which favour finding these records privileged with those which favour production." 46

certiorari to a superior court, the outcome of which can then be appealed through the regular channels of the judicial system. Appeals from interlocutory decisions of superior courts will be heard directly by the Supreme Court of Canada pursuant to s. $40(1)$ of the Supreme Court Act, R.S.C. 1985, c. S-26. The Supreme Court has expressed dissatisfaction with hearing direct appeals, and has called for legislation to provide a right of appeal for superior court interlocutory decisions to the relevant provincial court of appeal. See Dagenais at 874, R. v. McClure, [2001] I S.C.R. 445 at para. 66; R. v. Brown, (2002), 210 D.L.R. (4th) 341 (S.C.C.) at paras. 109-10. L'HeureuxDubé J., in dissent in Dagenais, rejected a third-party right of appeal for interlocutory orders, and expressed concerns about the "significant delay" this would cause to the trial process (at para. 112). See also the dissenting judgment of La Forest J. at para. 105.

Mills, supra note 11.

A.(L.L.), supra note 24 at para. 39.

Ibid. at para. 65. The concerns were: "(1) the truth-finding process of our adversarial trial procedure; (2) the possible relevance of some private records; (3) the accused's right to make full answer and defence; (4) the categories of actors included in a class privilege; and (5) the experience of other countries."

The Court noted that many state courts have found absolute privilege to be unconstitutional, although the United States Supreme Court had not yet ruled on the issue. See ibid. at paras. 45-46. Ibid. at para. 75. This approach is consistent with the Court's earlier decision in M.(A.) v. Ryan, [1997] 1 S.C.R. 157, where it considered the proper scope of production of records in the context of a civil sexual assault trial. In that case, the Court held that the issue of privilege must be determined on a case-by-case basis, with regard to the "Wigmore test" (at para. 7). First, the communication must originate in a confidence. Second, confidence must be an essential element of the relationship in which the communication arises. Third, the relationship must be one which should be "sedulously fostered" in the public good. Finally, if all these requirements are met, the court must consider whether the interests served by protecting the communications from disclosure outweigh the interest in getting at the truth and disposing correctly of the litigation.

Jbid. at para. 75. 
It is important to note that $O^{\prime}$ Connor and $A$.(L.L.) deal with the production of thirdparty records generally, and not just in the sexual assault context. At the same time, it was no coincidence that the issue of production first arose in sexual assault cases, as that is where most such applications were being made at the time. ${ }^{47}$ Still, $O^{\prime}$ Connor will continue to apply to those cases outside the sexual assault context where the production of third-party records is sought. ${ }^{48}$ Production applications in sexual assault cases are now governed by provisions of the Criminal Code enacted by Bill C-46, to which I now turn.

\section{Post O'Connor Developments: Bill C-46 and R. v. Mills}

\section{A. BiLL C-46}

Before $O^{\prime}$ Connor and $A .(L . L$.$) , Justice Canada had commenced a consultative process$ to achieve a legislative solution to the disclosure dilemma that would protect all of the rights at play in the context of sexual violence cases. This process carried on after $O^{\prime}$ Connor and $A$.(L.L.), resulting in Bill C-46 (the "production provisions"), which came into force on 12 May 1997.49 The Preamble to the Bill sets out its underlying principles: Parliament's "grave concern" for the incidence of sexual violence in Canadian society, particularly against women and children; Parliament's recognition that violence is an issue engaging the rights of women and children to security of the person, privacy and equality; Parliament's intention to protect and promote the Charter rights of those accused of, and who are victims of, sexual violence, and its recognition that in the event of a conflict, those rights are to be accommodated and reconciled to the greatest extent possible; and Parliament's desire to encourage the reporting of sexual violence and counselling of victims.

The production provisions apply to all sexual offences, ${ }^{50}$ and depart from the majority decision in $O^{\prime}$ Connor in several important respects. ${ }^{51}$ First, the two-step test for production now applies to all records relating to the complainant, including those in the possession of the Crown, in the latter case unless the complainant or witness to whom the record relates waives the application of this part of the Criminal Code. ${ }^{52}$ Thus in sexual assault cases, Bill C-46 legislates a departure from Stinchcombe for Crown disclosure, justified by the concerns set out in the Preamble.

A second difference between $O^{\prime}$ Connor and the production provisions is that the list of factors to be taken into account before ordering production has been expanded to include society's interest in reporting sexual offences and in encouraging counselling

Busby (1997), supra note 13 at 151 .

See Wayne Renke's contribution to this issue at 593.

An Act to Amend the Criminal Code (production of records in sexual offence proceedings), S.C. 1997, c. 30 [hereinafter Bill C-46]. The Bill added ss. 278.1 to 278.91 to the Criminal Code. R.S.C. 1985 , c. C-46.

Criminal Code, ibid., s. 278.2(1).

In many of these respects, Bill C-46, supra note 49 , closely resembles the dissenting reasons in $O{ }^{\prime}$ Connor, supra note 21.

Criminal Code, supra note 49, s. 278.2(2). The Crown must give notice to the accused of its possession of records relating to the complainant or witness. 
of survivors, and the effect of production on the integrity of the trial process. ${ }^{53}$ The trial court must now weigh these factors at the first stage of the process in deciding whether to review the records in the first place.

The production provisions also list a number of examples of what will be "insufficient" to establish likely relevance, including mere assertions by the accused that: ${ }^{54}$

- the record exists;

- the record relates to counselling or treatment;

- the record may relate to the credibility of the complainant, or the reliability of her testimony merely because she has received counselling; or

- the record relates to the complainant's sexual activity with another person, or her sexual reputation.

Finally, the production provisions add the criterion of "necessary in the interests of justice" to those which must be satisfied before a judge can order production of private records. ${ }^{55}$ Before Bill C-46, the criteria were limited to "likely relevance" and compliance with the procedures established in $O^{\prime}$ Connor.

While many women's groups would have preferred a "no records, any time" response, they supported Bill C-46 as a positive improvement on the $O^{\prime}$ Connor decision. Several recommendations for the reform of Bill C-46 were made, but most were ultimately rejected by Parliament. The recommendations included:

- incorporation of the Preamble into the text of the Criminal Code as an interpretive provision or declaration of principles, and an elaboration of the Preamble to acknowledge the discriminatory nature and impact of production applications; ${ }^{56}$

- an expanded definition of "personal records"; ;7

- addition of other insufficient grounds for producing records, and a stipulation that the listed grounds are insufficient by themselves or in combination; ${ }^{58}$

lbid., s. 278.5(2).

Ibid., s. 278.3(4).

Ibid., s. 278.5(1)(c).

See J. Scott \& S. McIntyre, Women's Legal Education and Action Fund (LEAF) Submissions to the Standing Committee on Justice and Legal Affairs (March 1997) at 31-32 [hereinafter LEAF Submissions]; D. Oleskiw \& N. Tellier, Submissions to the Standing Committee on Bill C-46 prepared for the National Association of Women and the Law (March 1997) at 16-19 [hereinafter NAWL Submissions]. The Bloc Québécois also supported the inclusion of the Preamble in the body of the Criminal Code, ibid. See Canada, House of Commons Debates (17 April 1997) at 9851.

LEAF Submissions, ibid. at 32-33, arguing for the explicit inclusion of "sexual assault crisis and care centre records, young offender and adult correctional records, and child protection" records. LEAF Submissions, ibid. at 34; NAWL Submissions, supra note 56 at 23-26. One ground was added to the final version of Bill C-46, supra note 49 , based upon these submissions: $s$. $278.3(4)(k)$ created the insufficient ground "that the record was made close in time to a complaint or to the activity that forms the subject-matter of the charge against the accused." 
- state-funded counsel for complainants and record holders defending their records from production. ${ }^{59}$

Given the departure of Bill C-46 from the majority decision in $O^{\prime}$ Connor, it was virtually guaranteed that the production provisions would eventually be subjected to a Charter challenge. Several such challenges were mounted, and it was an Alberta case, Mills, that eventually came before the Supreme Court of Canada on this issue.

\section{B. MILLS}

Brian Joseph Mills was charged with one count of sexual assault and one count of unlawful sexual touching, alleged to have occurred when the complainant L.C. was 13. Before trial, the accused sought several records relating to the complainant, including those of a psychiatrist, the Child and Adolescent Services Association, and a counselling organization called "Changes." The basis for this application was that the records might show the complainant fabricated the allegations, had a motive for doing so, and was highly suggestible to the influences of her counsellors. ${ }^{60}$ This request for production occurred two days after Bill C-46 came into effect, leading defence counsel to mount a constitutional challenge to the production provisions.

Justice Belzil of the Alberta Court of Queen's Bench held that the production provisions violated ss. 7 and 11(d) of the Charter, and could not be justified under s. $1 .^{61}$ The basis for this decision, in large part, was the finding that Bill C-46 materially altered the balance between the rights of the accused and complainant established by the majority decision in $O^{\prime}$ Connor.

On appeal to the Supreme Court of Canada, ${ }^{62}$ the defence maintained its argument that the departure of Bill C-46 from $O^{\prime}$ Connor was sufficient to result in a finding of unconstitutionality. This argument was supported by several intervenors representing the rights of accused persons. ${ }^{63}$ Five problems with the Bill were identified: (1) the definition of "records," (2) the extension of the production regime to records in the possession of the Crown, (3) the "insufficient grounds" section, (4) the altered test for production to the judge at the first stage of the application, and (5) the factors to be considered at the second stage of the production application - in other words, all of the ways in which the Bill departed from the majority decision in $O^{\prime}$ Connor.

The complainant, L.C., argued that the production provisions should be upheld as achieving an appropriate balance between the constitutional rights of complainants and accused persons. Several intervenors also supported the legislation: the Attorneys

60 This was said to constitute the "theory of the defence." See Intervenor's factum, Women's Legal Education and Action Fund (LEAF) in Mills, supra note 11 at para. 30.

61 (1997), 205 A.R. 321; 207 A.R. 161 (Q.B.).

62 This was a direct appeal to the Supreme Court from a superior court decision, pursuant to $A .(L . L$.$) ,$ supra note 24 and Dagenais, supra note 40.

63 These were the Criminal Lawyers' Association (Ontario), the Canadian Civil Liberties Association, and the Canadian Council of Criminal Defence Lawyers. 
General of Canada, Ontario, Quebec, Nova Scotia, Manitoba, B.C., P.E.I., and Saskatchewan; LEAF; the Alberta Association of Sexual Assault Centres (AASAC); and the Sexual Assault Centre of Edmonton. ${ }^{64}$

According to the equality-seeking intervenors in Mills, Parliament had a duty to respond to the $O^{\prime}$ Connor decision with legislation, given the omission of equality rights from the reasoning of the majority of the Court in that case. In arguing that production of records is a practice of inequality, LEAF and AASAC noted the adverse impact of production on women and children, particularly those whose lives are heavily documented - often women who are already disadvantaged because of their poverty, race, class, and mental health histories. ${ }^{65}$ Other aspects of inequality noted by the intervenors include the fact that the overwhelming majority of applications for production of third-party records are made in sexual assault cases, ${ }^{66}$ suggesting the presence of myths and stereotypes about women and their reliability in this context. Moreover, new myths have developed concerning counsellors and therapists, who are mostly women, and their influence over sexual assault survivors. ${ }^{67}$ These intervenors urged the Court to develop principles and guidelines for the proper interpretation of the production provisions, to ensure that the Charter's equality guarantees were not diminished upon application. ${ }^{68}$

The Supreme Court's decision in Mills was released in November of 1999, with a majority of the Court upholding the production provisions in their entirety. The Court began its decision by noting the conversation at play in this area. Writing for the majority, McLachlin and lacobucci JJ. stated,

it does not follow from the fact that a law passed by Parliament differs from a regime envisaged by the Court in the absence of a statutory scheme, that Parliament's law is unconstitutional. Parliament may build on the Court's decision, and develop a different scheme as long as it remains constitutional. Just as Parliament must respect the Court's rulings, so the Court must respect Parliament's determination that the judicial scheme can be improved. To insist on slavish conformity would belie the mutual respect that underpins the relationship between the courts and legislature that is so essential to our constitutional democracy.

The history of the treatment of sexual assault complainants by our society and our legal system is an unfortunate one. Important change has occurred through legislation aimed at both recognizing the rights and interests of complainants in criminal proceedings, and debunking the stereotypes that have been so damaging to women and children, but the treatment of sexual assault complainants remains an ongoing problem. If constitutional democracy is meant to ensure that due regard is given to the voices

I participated in drafting the intervenor factum of AASAC. Mills, supra note 11 (Intervenor's factum, Alberta Association of Sexual Assault Centres) [hereinafter AASAC, Mills factum]. Mills, supra note 11 (LEAF Intervenor's factum at para. 25) [hereinafter LEAF, Mills factum] citing Busby (1997), supra note 13 and MacCrimmon, supra note 38. September 1996, 120 occurred in cases involving sexual offences, and of the other 20 cases, 14 involved offences of violence and 8 related to records of women or children. 
of those vulnerable to being overlooked by the majority, then this court has an obligation to consider respectfully Parliament's attempt to respond to such voices. ${ }^{69}$

Before ruling upon the specific complaints about the provisions, the Court outlined the rights at issue in the production context: the accused's right to liberty and to make full answer and defence, the complainant's right to privacy and to be free from unreasonable search and seizure, the complainant's right to security of the person, and the complainant's right to equality, including an appreciation of how myths and stereotypes may underlie disclosure applications. Moreover, the Court recognized the importance of protecting counselling and other "trust-like" relationships:

That privacy is essential to maintaining relationships of trust was stressed to this Court by the eloquent submissions of many intervenors in this case regarding counselling records. The therapeutic relationship is one that is characterized by trust, an element of which is confidentiality. Therefore, the protection of the complainant's reasonable expectation of privacy in her therapeutic records protects the therapeutic relationship.

The values protected by privacy rights will be most directly at stake where the confidential information contained in a record concerns aspects of one's individual identity or where the maintenance of confidentiality is crucial to a therapeutic, or other trust-like, relationship. ${ }^{70}$

Ultimately, a majority of the Court rejected all of the defence arguments and found that the production provisions properly balanced the rights identified in this context. It is significant to note that Lamer C.J.C. upheld the legislation, apart from its application to records in the possession of the Crown, along with Major and lacobucci JJ., all of whom had been in the majority in $O^{\prime}$ Connor.

On the one contentious issue in the case, the majority interpreted $O^{\prime}$ Connor to have held that private records in the possession of the Crown must be disclosed as per Stinchcombe only where the privacy in the records had been waived by the complainant. ${ }^{71}$ The majority found that Crown possession or control of personal records could not be equated with "a total loss of any reasonable expectation of privacy," such that "Parliament can legitimately take steps to protect those privacy rights" as it did in Bill C-46. ${ }^{72}$ The fact that Bill C-46 legislated a different regime from Stinchcombe for records in the hands of the Crown was not found to render it unconstitutional, nor did any "advantageous documentary position" on the part of the Crown have this effect. ${ }^{73}$

Chief Justice Lamer dissented on this point, holding that the application of the production provisions to records in the Crown's possession or control "supplant[s] the presumption of relevance" for such records, and "raises the relevance bar" by applying the test of likely relevance rather than "useful to the defence" (the Stinchcombe 
standard). ${ }^{74}$ In Lamer C.J.C.'s view, these concerns were not offset by the requirement that the Crown notify the accused of records in the possession of the prosecution, ${ }^{75}$ as the defence must argue these are likely relevant without having an opportunity to see them. Chief Justice Lamer's proposed solution was the application of a modified Stinchcombe approach, where the Crown would have the opportunity to rebut the presumption of the records' relevance, failing which the records would be reviewed by the trial judge to determine whether they should be produced to the defence according to the factors in the production provisions. ${ }^{76}$

Sankoff argues that the majority's interpretation of $O^{\prime} C o n n o r$ is incorrect, and that the basis for distinguishing Stinchcombe - that it did not concern private records is "remarkable" and "precarious." "Th The Court's interpretation of $O^{\prime}$ Connor is significant, as it must be remembered that this case will continue to apply to applications for production and disclosure outside the scope of Bill C-46. Thus it appears that applications for disclosure of private records in the hands of the Crown are not subject to Stinchcombe in non-sexual assault cases; rather they should be seen as subject to $O^{\prime}$ Connor, or perhaps even to the production provisions. ${ }^{78}$

While Mills is a positive decision for those seeking to protect records from production in that it upholds Bill $\mathrm{C}-46$ as a constitutionally sound alternative to $O$ 'Connor, there are several aspects of the judgment that raise concern from this perspective.

One important feature of the decision is the Court's approach to dealing with the various rights engaged by production applications. The Court perceived that it was applying a non-hierarchical approach to rights:

On the one hand stands the accused's right to make full answer and defence. On the other hand stands the complainant's and witness's right to privacy. Neither right may be defined in such a way as to negate the other and both sets of rights are informed by the equality rights at play in this context.

No single principle is absolute and capable of trumping the others; all must be defined in light of competing claims. ${ }^{79}$

74 Ibid. at para. 8.

is Criminal Code, supra note 49, s. 278.2(3).

76 Mills, supra note 11 at para. 14.

$7 \quad$ P. Sankoff, "Crown Disclosure after Mills: Have the Ground Rules Suddenly Changed?" (2000) 28 C.R. (5th) 285 at 289.

7 The argument that cases outside the sexual assault context should be interpreted in light of the production provisions will be addressed below, Part V. Busby (2000), supra note 25 at 374 , notes that the issue of whether documents are in the control of the Crown has been a contentious one since $O^{\prime}$ Connor.

79 Mills, supra note 11 at paras. 17,61 . See also Dagenais, supra note 40 at para. 80 , where the Court noted that a "clashing titans" model of rights was to be avoided. 
The importance of this interpretative approach should not be overlooked. ${ }^{80}$ Rather than weighing complainants' "interests" under s. 1 in terms of whether a violation of the accused's rights can be justified, the Court acknowledged that complainants possess "rights" which must be considered in defining the scope of the rights of the accused. Waiting for s. 1 to consider the rights of complainants places the onus on the government to justify overriding the rights of the accused. As these rights have already been found to be violated, the s. 1 analysis begins with the balance tipped to one side. The Court's approach in Mills seeks to achieve equilibrium in defining the scope of each right, such that there may be no violation to justify. In Mills, this approach was summarized as follows:

[T]he scope of the right to make full answer and defence must be determined in light of privacy and equality rights of complainants and witnesses. It is clear that the right to full answer and defence is not engaged where the accused seeks information that will only serve to distort the truth-seeking purpose of a trial, and in such a situation, privacy and equality rights are paramount. On the other hand, where the information contained in a record directly bears on the right to make full answer and defence, privacy rights must yield to the need to avoid convicting the innocent. Most cases, however, will not be so clear, and in assessing applications for production, courts must determine the weight to be granted to the interests protected by privacy and full answer and defence in the particular circumstances of each case. Full answer and defence will be more centrally implicated where the information contained in a record is part of the case to meet or where its potential probative value is high. A complainant's privacy interest is very high where the confidential information contained in a record concerns the complainant's personal identity or where the confidentiality of the record is vital to protect a therapeutic relationship. ${ }^{81}$

Several commentators are critical of the Court's approach to rights in Mills. Stuart argues that s. 15 was applied "by assertion" rather than pursuant to the test in Law v. Canada, amounting to an adoption of "the political equality polemic of the day." 82 Pomerance writes that the case may resurrect the argument that violations of $\mathrm{s} .7 \mathrm{can}$ be saved under s. 1 of the Charter, and questions whether s. 7 is now "designed to reconcile conflicting rights, while $s .1$ is driven by a more combative or hierarchical approach." ${ }^{83}$ Pringle argues that "the court let the state off the hook from having to justify the limits that the legislation imposed under s. $1 .{ }^{n 4}$ Cameron contends that the Court failed to adopt a non-hierarchical approach to rights, placing the rights of

See J. McInnes \& C. Boyle, "Judging Sexual Assault Law Against a Standard of Equality" (1995) 29 U.B.C. L. Rev. 341 at 355.

81 Mills, supra note 11 at para. 94.

82 D. Stuart, "Mills: Dialogue with Parliament and Equality by Assertion at What Cost?" (2000) 28 C.R. (5th) 275 at 279-81. Jamie Cameron also critiques the Court's approach to s. 15, noting that this seems to depend on the other right with which $\mathrm{s}$. 15 is to be balanced. See J. Cameron, "Dialogue and Hierarchy in Charter Interpretation: A Comment on R. v. Mills" (2000) 38 Alta. L. Rev. 1051 at 1066. (2000) 8 Canada Watch 36 at 38. 
complainants above those of the accused. ${ }^{85}$ The reverse could also be argued, as the Court finds that the trial judge should resolve doubts in favour of production, ${ }^{86}$ clearly favouring the rights of the accused. From either perspective, the Court does not fulfill the promise of a non-hierarchical approach to rights in the end.

Another aspect of the decision meriting comment is the degree of deference shown by the Court to Parliament. The Court frames this deference in terms of a "dialogue" with Parliament, and sees the notion of dialogue as enhancing democracy. The Court specifically refers to the extensive consultations around Bill C-46 in this regard. ${ }^{87}$

The Court's deferential approach is criticized by Stuart, who argues that "Parliament could not have been clearer in its intent to enact 'in your face' legislation to overcome an unpopular Charter ruling." judges as guardians of the Charter, where a presumption of constitutionality is inappropriate. Cameron critiques the Court's deference to Parliament as a subterfuge for conceding that it was overruling $O^{\prime} C_{0}$ nnor. ${ }^{89}$ In contrast, Coughlan argues that Mills does not in fact take a deferential approach, and reads down the production provisions in several important respects, marking a return to $O^{\prime}$ Connor.$^{90}$

If Mills is deferential to Parliament, which is clearly debatable, this is consistent with other cases providing for such deference where the legislature is protecting a vulnerable group, although normally this analysis occurs under s. $1 .{ }^{91}$ More importantly, the legislative process involved in the enactment of Bill C-46 was arguably a democratic one, involving public consultations with groups representing the range of interests in the production context. ${ }^{92}$ The Court rightly recognizes that adherence to a democratic process - making dialogue a conversation - is an important factor when deciding the level of deference to accord the legislatures. ${ }^{93}$

Cameron, supra note 82 at 1064-65. Cameron also notes that while the balancing of rights took place under s. 1 in Dagenais, the Supreme Court used s. 7 as its vehicle for balancing in Mills. Mills, supra note 11 at para. 132.

Ibid. at para. 59.

Stuart, supra note 82 at 276. See also A.D. Gold, "Moving into the Millennium" (2000) 21:1 For the Defence 4 , where the author calls Bill C-46 a "legislative slap in the face to the Supreme Court."

Cameron, supra note 82 at 1052.

S. Coughlan, "Complainants' Records After Mills: Same As It Ever Was" (2000) 33 C.R. (5th) 300 .

See, e.g., Irwin Toy v. Quebec, [1989] I S.C.R. 927; R. v. Butler, [1992] I S.C.R. 452; R. v. Sharpe, [2001] I S.C.R. 45. I have some distaste in generally categorizing women as a "vulnerable group," as this tends to present women as passive victims rather than active participants in their own lives. Women's vulnerability in the sexual assault context is less problematic, given the dynamics of power and control at play here.

This is disputed by some defence lawyers, who argue that "the rights of the accused were simply washed away by a massive lobby of women's and victims' groups." See interview with A. Gold, President of the Criminal Lawyers Association, in K. Makin, "Ruling 'a sign of things to come"" Globe \& Mail (27 November 1999) A3, cited in Stuart, supra note 82 at 279.

Mills, supra note 11 at 59. See also M. Jackman, "Protecting Rights and Promoting Democracy: Judicial Review Under Section I of the Charter" (1996) 34 Osgoode Hall L.J. 661, who argues at 679 that under s. I, "judges should pay careful attention to the democratic quality of government decisions." Cameron, supra note 82 at 1061, disagrees with this view, arguing that it amounts to 
Other criticisms of Mills are more concrete, and relate to the Court's interpretation of specific production provisions. First, the Court broadly defined the notion of waiver. Section 278.2(2) of the Criminal Code provides that if the complainant or witness expressly waives the application of the production provisions, they do not apply to records in the possession of the Crown. The Court defined the test for waiver as follows:

Where the complainant or witness, with knowledge that the legislation protects her privacy interest in the records, indicates by words or conduct that she is relinquishing her privacy right, waiver may be found. Turning records over to the police or Crown, with knowledge of the law's protections and the consequences of waiving these protections, will constitute an express waiver pursuant to $s$. $278.2(2) .^{94}$

This test arguably diminishes the distinction between Stinchcombe and the production provisions relating to records in the possession of the Crown. ${ }^{95}$ Moreover, it is important to note that waiver is for the complainant or witness to make, not the record holder. Mills does not recognize the possibility that a record holder may have an interest in protecting records from production even where the complainant waives her rights - another criticism of the case. While not all record holders will have women's privacy and equality interests at heart, some may seek to shelter records from production even where the complainant consents, based on broader concerns about protecting the privacy of women's stories, and encouraging complainants to report sexual assault and to seek counselling. ${ }^{96}$ This has been recognized procedurally, in providing record holders with standing in production applications, but Mills does not recognize the interests of record holders in a more substantive way.

Another important aspect of Mills relates to the Court's interpretation of the "insufficient grounds" section (s. 278.3(4)). Lower court cases before Mills were divided on the question of whether the grounds set out there could not be relied on at all, or could be relied on in combination, or alone with an adequate evidentiary foundation. ${ }^{97}$ The Supreme Court found that s. 278.3(4) does not prevent the accused from relying on the assertions, rather it requires that the assertions be accompanied by evidence which supports the likely relevance of the records. ${ }^{98}$ While the requirement of an evidentiary foundation is better than assuming likely relevance in relation to

a determination of constitutionality using "process criteria."

Ibid. at para. 114.

Coughlan, supra note 90 at 305 , agrees with this view.

Christine Boyle has noted that rape crisis centres may seek the protection of records from disclosure "in the interests of sexual assault victims generally." See C. Boyle, "The Case of the Missing Records: $R$. v. Carosella" (1997) 8 Const. Forum 59 at 63.

97 Busby (2000), supra note 25 at 380.

98 Mills, supra note 11 at para. 120. Stuart, supra note 82 at 283 , notes with approval that this amounts to a reading down of s. 278.3(4), while Coughlan, supra note 82 at 305 , argues that this interpretation is consistent with a plain reading of the section. LEAF and NAWL had recommended to the Standing Committee on Justice and Legal Affairs that this section be amended to clarify that the grounds are "impermissible" alone or in combination, to avoid the interpretation adopted by the Court in Mills. See LEAF Submissions, supra note 56 at 34; NAWL Submissions, supra note 56 at 23. 
particular records, as the majority did in $O^{\prime}$ Connor, it would have been preferable if the Court had recognized that some claims of relevance, by their very nature, cannot be supported. Surely this should be the case for claims based upon outdated legal principles, such as the relevance of evidence relating to recent complaint or sexual reputation. $^{99}$

Further, the Court acknowledges and accedes to the Catch-22 analysis put forward by the defence in Mills: if they can't see the records, how can they argue their relevance? As in $O^{\prime}$ Connor, the Court finds that this consideration may override competing concerns in order to protect the right to make full answer and defence in certain circumstances, ${ }^{100}$ clearly placing the rights of the accused at the top of the hierarchy. While the Catch- 22 reasoning is not unique to the production context, ${ }^{101}$ it is arguably less important here, as sexual offences are committed most often by someone known to the victim, in which case that person would likely have knowledge of the existence of records, the kinds of information they might contain, and their potential relevance. ${ }^{102}$

An overarching concern with Mills is the broad discretion left to trial judges to interpret the production provisions as they see fit. The Court specifically noted and confirmed the discretionary nature of the decision making at both the first and second stages of production applications, presuming that Parliament intended the discretion to be exercised "in a manner consistent with the Charter principles discussed above." 103 Moreover, while the factors set out in s. $278.5(2)$ are to be "taken into account" in deciding whether to order production, the Court found that the trial judge need not engage in a "conclusive and in-depth evaluation" of each one. Further, at the first stage of the production application, the judge need only consider the factors "to the extent possible at this early stage of proceedings." 104 In the end, the trial judge is to make whatever order he or she considers "necessary in the interests of justice." The Court is unclear with respect to the import of this criterion, added in Bill C-46. While at some points in its judgment the Court describes this standard as encompassing the rights of complainants and accused persons, and allowing for a balancing of these interests, ${ }^{105}$ it suggests elsewhere that this criterion exists primarily for the protection of the accused. $^{106}$

The rules regarding recent complaint, which permitted an adverse inference to be drawn where the complainant had not raised a "hue and cry" soon after being sexually assaulted, were abrogated in 1983. See Criminal Code, supra note 49, s. 275. Evidence of the complainant's sexual reputation has been inadmissible in criminal proceedings since 1983. See s. 277 of the Criminal Code, which was upheld as constitutional in Seaboyer, supra note 22. Mills, supra note 11 at paras. 71, 76, 137.

Dersch v. Canada (A.G.), [1990] 2 S.C.R. 1505, at 1513-14; $R$. v. Garofoli, [1990] 2 S.C.R. 1421 at 1463-64; Carey v. Ontario, [1986] 2 S.C.R. 637; $R$. v. Durette, [1994] I S.C.R. 469 at 499, all cited in $O^{\circ}$ Connor, supra note 18 at para. 25.

Busby (2000), supra note 25 at 357,361 .

Mills, supra note 11 at para. 123. See also paras. 130, 132.

Ibid. at para. 134. See also para. 14I. Coughlan, supra note 90 at 306-307, is also critical of this aspect of Mills.

Ibid. at paras. 125-26, 131 .

Ibid. at paras. 137-38. 
Overall, to the extent it did not render Bill C-46 hollow, the majority decision in Mills was a welcome one for those seeking to protect irrelevant personal records from production. ${ }^{107}$ Whether the concerns raised here are valid ones depends in large part on how the production provisions are interpreted by the lower courts subsequent to Mills, a matter to which I now turn.

\section{JUdiCial Decisions Since MiLls}

It is important to begin this section of the article with a caveat: this survey of postMills cases is likely incomplete. While reasons for a court's decision on production must be given and entered into the record of the proceedings, ${ }^{108}$ it appears that the decisions are not often reported. ${ }^{109}$ This is typical of interlocutory matters, and may explain the small number of cases found by searching traditional legal databases. ${ }^{10}$

On the other hand, the small number of production decisions subsequent to Mills contrasts with the relatively large number of cases that were reported prior to Mills, ${ }^{\prime \prime}$ leading to the possible conclusion that fewer applications for production are being made since Mills. Informal conversations with Crown and defence counsel, as well as sexual assault centre workers and complainants' counsel, suggest this may be the case. ${ }^{112}$ From the perspective of those seeking to prevent discriminatory practices in sexual assault trials, this would certainly be a positive outcome of their advocacy around Bill C-46 and Mills.

Another possibility is that lawyers may be using other means to obtain records, including applications under provincial freedom of information legislation. This raises some interesting issues. First, if the accused does come into possession of records through means other than an application under the Criminal Code, do the criteria in the production provisions still have to be met before the accused can use the records in a sexual assault proceeding? This issue arose in a B.C. case, $R$. v. Shearing, where the

Elizabeth Grace concludes that Mills "represents a significant step forward in recognizing the individual and social utility in preserving the confidential, trust-like relationships between health care providers and the sexual abuse victims they treat and counsel." See E. Grace, "Case Comment: $R$. v. Mills - Production of Health Records in Criminal Sexual Abuse Cases" (2000) 1 J. Women's Health \& L. 279 at 292.

Wrox Criminal Code, supra note 49, s. 278.8.

wey See, e.g., R. v. C.M.E., [2001] A.J. No. 1602 (Q.B.), online: QL (AJ), where in ruling on the admissibility of expert evidence, the court refers to an earlier application for production that is not reported.

1ii' Searches were conducted using Quicklaw and eCarswell, as well as the Canadian Statute Citator, for the period December 1999-December 2001.

III For a discussion of cases decided between O'Connor and Mills, see Busby (2000), supra note 25. Busby's research uncovered 47 cases decided in the 16 months between $O^{\prime}$ Connor and Bill C-46, and 33 cases decided in the 12 months after Bill C-46 came into effect.

112 Grace, supra note 107 at 292, predicts that production applications will become less frequent over time. Defence counsel have noted the "great risks" associated with production applications, although these would have existed to the same degree before Mills. See S. Skurka \& E. Renzella, "Defending a Sexual Assault Case: Third Party Record Production" (2000) 21:2 For the Defence $2(\mathrm{QL})$, where the authors note the risks inherent in bringing personal records to the attention of the trier of fact where such records "may contain an abundance of sympathetic material regarding the fragile emotional state of the complainant attributed to [the accused]." 
accused was in possession of the diary of one of the complainants, and sought to crossexamine her on its contents at trial. ${ }^{113}$ On appeal to the Supreme Court, LEAF argued that the production provisions must be applied even where the accused is already in possession of the records, before such records can be used at trial. This was said to accord with the proper interpretation of s. 278.2(2) of the Criminal Code, which provides that the production provisions apply "where a record is in the possession or control of any person." LEAF also argued that such an interpretation would dissuade the accused from gaining possession of records by illegal or improper means. ${ }^{1 / 4} \mathrm{~A}$ majority of the Supreme Court of Canada rejected this argument, holding that to apply the production provisions to records in the possession of the accused would be to "twist [their] language." M/s Moreover, the majority found that the case did not engage the concerns underlying the production provisions: protection of confidential relationships, and encouragement of sexual assault victims to seek counselling and to report sexual offences. $^{116}$ This narrow view of the purpose and scope of the production provisions precludes the argument that where the accused comes into possession of records through an application under freedom of information legislation or another manner subverting the spirit of the provisions, he should be obliged to meet the requirements of the provisions before using the records at trial.

The second issue that arises in the case of applications for records under provincial legislation is the possibility of a conflict between the provincial legislation and the federal Criminal Code. According to the doctrine of paramountcy, federal legislation will prevail where it conflicts with provincial legislation. ${ }^{117}$ It could be argued that provincial freedom of information legislation, to the extent it would permit production of government records to an accused without consideration of the records' relevance and necessity to the interests of justice, and without the procedural safeguards and participation of complainants guaranteed by the production provisions, conflicts with the more restrictive procedures in the Criminal Code, and should thus be inoperative in the sexual assault context. ${ }^{118}$

11. Shearing, the leader of a religious organization based in Vancouver, was charged with 20 counts of sexual offences against 11 complainants, his followers and their children. See James Pickard's comment on Shearing in this issue at 743.

$R$ v. Shearing, [2002] S.C.J. No. 59, online: QL (SCJ) (LEAF Intervenor's factum at para. 14) [hereinafter Shearing]. The author was a member of LEAF's case committee on Shearing.

Shearing, ibid. at para. 97. In dissent on this issue, L'Heureux-Dube and Gonthier JJ. were of the view that "the trial judge should have ordered the diary, as well as every copy that was made of it, returned to its rightful owner and required the appellant to seek production of it through the proper statutory scheme, ... just as any other accused person in his position would have had to" (at para. 161).

116 Ibid. at para. 95. This characterization of the provisions is consistent with Busby's observation of the Court's decisions on production: "the Supreme Court of Canada has treated the issue of records disclosure as though it involved only counselling or therapy records despite the fact that records applications before lower courts involve almost every imaginable record." Busby (2000), supra note 25 at 370 .

117 For a recent case on the doctrine of paramountcy see M\&D Farm v. Manitoba Agricultural Credit Corp., [1999] 2 S.C.R. 961.

118 In Alberta, see the Freedom of Information and Protection of Privacy Act, R.S.A. 2000, c. F-25. Generally, the $A c t$ permits access to information held by public bodies, subject to the confidentiality and privacy of the information. Notice must be given to a third party that information relating to them is sought, and the party has an opportunity to consent or object to the 
To the extent that applications for production of records continue to be made, there is potential for a host of appellate decisions in these cases. As noted in A.(L.L.), appeals of production orders may be brought by complainants and record holders in addition to the Crown and defence. Another possibility is that production decisions may form one of the grounds for a Crown or defence appeal of an acquittal or conviction. Section 278.91 of the Criminal Code provides that "a determination to make or refuse to make [a production order] ... is deemed to be a question of law," giving rise to a right of appeal by the defence or Crown. ${ }^{119}$

\section{A. Supreme Court of Canada}

To date, only a couple of cases from the Supreme Court of Canada have considered issues relating to production of third party records since Mills. In R. v. McClure, ${ }^{120}$ the Court returned to the issue of production in the sexual assault context, but this time, the issue was the interaction between solicitor-client privilege and the accused's right to full answer and defence. This issue arose when the accused teacher sought production of a civil litigation file in relation to the complainant's claim for damages against him. In resolving the issue, the Court held that solicitor-client privilege is not absolute, and must give way to the accused's right to full answer and defence where the innocence-at-stake exception is met. ${ }^{21}$ This is a two-stage test that requires first, inquiry into whether the evidence in question could raise a reasonable doubt as to the accused's guilt. As in the two-stage test for production set out in the Criminal Code, mere speculation will not suffice to meet the burden at this stage of the test; rather, evidence is required. ${ }^{122}$ If the first stage is met, the court will review the file to determine whether it contains evidence on a material issue that is likely to raise a reasonable doubt about the accused's guilt. ${ }^{123}$

This is obviously a stricter test for production than that set out in Bill C-46 and affirmed in Mills, and is justified on the basis of the historical support for protection of solicitor-client privilege. $\mathrm{McCl}$ ure was recently considered by the Supreme Court in $R$. v. Brown, where it noted that "McClure applications" are "stringent, and will only be satisfied in rare circumstances." 124 These decisions place into relief the Court's earlier holding in A.(L.L.) that there should be no class privilege for counselling records. This hierarchy of relationships has been criticized by Lise Gotell, who argues that the law is positioned "as a discrete and important realm of discourse above all

disclosure in writing. The $A c t$ also contains review procedures.

See Criminal Code, supra note 49, ss. 675, 676.

[2001] I S.C.R. 445 [hereinafter McClure].

Ibid. at para. 46.

Ibid. at paras. 51-53.

Ibid. at para. 57.

[2002] S.C.J. No. 35 at para. 29, online: QL (SCJ) [hereinafter Brown]. For a case where the innocence-at-stake exception was found to be met, see $R$. v. Castro, [2001] B.C.J. No. 1792 (C.A.), online: QL (BCJ), 157 C.C.C. (3d) 255, 47 C.R. (5th) 391, application for leave to appeal denied [2001] S.C.C.A. No. 533. In this case, a new trial was ordered after the trial judge refused disclosure of a legal opinion on the legality of a police undercover operation, as this opinion was found to be relevant to whether an abuse of process had occurred, and whether a stay of proceedings was the appropriate remedy in the case. 
others," including communications between sexual assault complainants and their counsellors, thereby "colonizing and silencing" the latter discourses. ${ }^{125}$

The $M c C l$ lure and Brown cases are also interesting in that there is no discussion of a Catch-22 for the defence where it must satisfy the test for production of a solicitor's file without seeing it. On the reasoning in Mills, a Catch-22 could have been found here, perhaps with even more strength given the more stringent test for production, but the Court did not advert to this alleged burden on the accused. This further underlines the problematic aspects of the Catch-22 analysis - if it applies to third-party records generally, why not to solicitor-client records as a subcategory of these? ${ }^{126}$

\section{B. Provincial Courts of APPEAL}

In the two-year period following Mills, there have only been a handful of court of appeal decisions on production issues. ${ }^{127}$ In one case from Ontario, $R$. v. Batte, ${ }^{128}$ the production provisions were arguably strengthened. ${ }^{129}$ Interestingly, the provisions did not actually apply in this case, as the production order being appealed from was made before Bill C-46 came into effect. Nevertheless, the Ontario Court of Appeal recognized that if the case went back to trial, the production provisions would govern any applications for production, and made its comments in this context. In Batte, the Court held that counselling records potentially relevant to the complainant's credibility would pass the likely relevance threshold "only if there is some basis for concluding that the statements have some potential to provide the accused with some added information not already available to the defence, or have some potential impeachment value." 130 The fact that the complainant had spoken to a counsellor about the alleged abuse was found to be insufficient to meet this test.

Batte has been followed in several other cases, where its reasoning has been extended to records other than those relating to counselling. ${ }^{131}$ The fact that Batte

L. Gotell, "Colonization Through Disclosure: Confidential Records, Sexual Assault Complainants and Canadian Law" (2001) 10 Social \& Leg. Stud. 315 at 322.

Boyle, supra note 96 at 61 , made a similar observation with respect to a constitutionally tolerable" Catch-22 for informer privilege.

$R$ v. Batte (2000), 49 O.R. (3d) 321 (C.A.) [hereinafter Batte]; R. v. B.P., [2000] O.J. 3852 (C.A.), online: QL (OJ); R. v. G.S., [2001] O.J. 1963 (C.A.), online: QL (OJ); R. v. P.E., [2000] O.J. 574 (C.A.), online: QL (OJ); R. v. G.P.J., [2001] 6 W.W.R. 734 (C.A.), 151 C.C.C. (3d) 382; R. v. E.A.N., [2000] B.C.J. 298 (C.A.), online: QL (BCJ). See also R. v. D.W.L. (200I), 194 N.S.R. (2d) 379 and $R$. v. Stewart (2000), 148 C.C.C. (3d) 68 (B.C. C.A.), involving applications for stays of proceedings in the production context.

Batte, ibid.

See J. Wilkinson, "Batte: Raising the Defence Hurdle for Access to Third Party Records" (2000) 34 C.R. (5th) 257.

Batte, supra note 127 at para. 72.

$R$ v. G.S., supra note 127 (notes of a community support worker); $R$ v. D.M., [2000] O.J. 3114 (Sup. Ct.), online: QL (OJ) (diaries); $R$. v. L.S., [2000] O.J. 3991 (Sup. Ct.), online: QL (OJ) (medical records); R. v. M.G., [2001] M.J. 61 (Prov. Ct.), online: QL (MJ) (child welfare records) [hereinafter M.G.]; and R. v. P.J.S., [2000] Y.J. 119 (S.C.), online: QL (YJ) (hospital records). See also R. v. S.P., [2001] O.J. 2898 (Sup. Ct.), online: QL (OJ); R. v. Thompson, [2001] O.J. 2900 (Sup. Ct.), online: QL (OJ); R v. L.G., [2000] O.J. 5090 (Sup. Ct.), online: QL (OJ) (counselling records). 
dealt with an $O^{\prime}$ Connor application rather than an application under the production provisions suggests that its test for likely relevance may also be applied to third-party records outside the sexual assault context. In this sense, the case points to the potential influence of Mills beyond the strict confines of the production provisions.

In one lower court production application, it was held that if evidence is available to the accused through cross-examination of the complainant at trial, the test from Batte will not be met. ${ }^{132}$ This ruling is indicative of Batte's double edge, as it may encourage defence counsel to engage in intense and invasive cross-examination of complainants at trial. ${ }^{133}$ The Supreme Court of Canada's recent decision in Shearing does little to assuage this concern. In Shearing, the Court overturned the decisions of the lower courts refusing cross-examination of a complainant on the lack of reference to sexual abuse in her diary. A majority of the Court specifically rejected the view of the B.C. Court of Appeal that Mills "casts a new light on the question of the complainant's privacy," and "shifted the balance away from the primary emphasis on the rights of the accused," 134 noting that "Mills itself affirms the primacy - in the last resort - of the requirement of a fair trial to avoid the wrongful conviction of the innocent." 135 Applying the traditional approach to the permissibility of questions on cross-examination, the majority found that the prejudice to the complainant by delving into her diary did not substantially outweigh its probative value, such that the trial judge should have permitted the cross-examination on the diary to proceed. ${ }^{136}$ With this ruling, the Court strayed even further from a non-hierarchical approach to rights, failing to recognize that fair trial rights must include equal consideration of the interests of complainants, even in the hallowed context of cross-examination.

A related issue is the extent to which defence counsel should be permitted to crossexamine complainants at preliminary inquiries in order to lay the foundation for production applications at trial. In another case concerning cross-examination on a complainant's diary, $R$. v. E.B., the Ontario Court of Appeal recently held that

questions of a witness at a preliminary inquiry concerning his or her private record are not impermissible per se; rather they suggest that the purpose and reach of each question must be assessed, to evaluate whether the question seeks to elicit information touching upon the "private or personal domain", or the "intensely private aspects" of the life or recordings of the author of the record. Assuming that the questions are otherwise relevant, only questions of the latter type would be impermissible. ${ }^{137}$

M.G., ibid.

Skurka \& Renzella, supra note 112 at 8, argue that "the defence will most likely have to broaden the scope of their cross-examination of the complainant asking pointed questions about counselling and its effect on the complainant's memory of the allegations and the decision to go to the police." They also suggest, at 7 , questions relating to substance abuse, and memory flashbacks, noting that "none of these questions infringe upon any expectation of privacy."

$R$ v. Shearing (2000), 143 C.C.C. (3d) 233 (B.C. C.A.) at paras. 83, 93.

Shearing, supra note 114 at para. 132.

Ibid. at para. 150. The majority ordered a new trial on the charges relating to this complainant.

L'Heureux-Dubé and Gonthier JJ. applied the same test, but dissented from the finding that the prejudice did not substantially outweigh the probative value (at para. $165 \mathrm{ff}$ ).

R. v. E.B. (2002), 57 O.R. (3d) 741 at para. 40 (C.A.) [hereinafter E.B.]. 
In concrete terms, the Court found that only questions going to the "exact contents of" or "actual entries in" the diary were impermissible, while questions such as whether a particular record exists, whether it contains descriptions of "encounters" between the accused and complainant, the ordering of information in the record, and the complainant's whereabouts during the time-frame of the alleged incidents were all permissible. Where a judge improperly refuses to permit questioning on a complainant's records at the preliminary inquiry, certiorari will be ordered. ${ }^{138}$

$E . B$. is a disconcerting case on several levels. Although it purports to apply the rights balancing approach from Mills, the case arguably guts the production provisions by giving the defence access to private information that would be inaccessible if sought in the context of a production application. Mills itself, along with L'Heureux Dubé J.'s reasons in $O^{\prime}$ Connor, are said to support the wide scope of cross-examination of complainants in preliminary inquiries. ${ }^{139}$ This problem flows from the way in which these cases frame production applications as involving evidentiary issues rather than impermissible grounds of relevance. Moreover, while the complainant is not a compellable witness in a production application, ${ }^{140}$ this protection will have little significance if she can be cross-examined on her records at the preliminary inquiry. Another troubling feature of the case is that the complainant was not independently represented by counsel on appeal. While standing has been found to exist for complainants and record holders in interlocutory applications and is codified in the production provisions, ${ }^{141}$ it is unclear whether they would have standing to challenge lines of cross-examination at a preliminary inquiry. It appears that cross-examination will continue to be a battleground on which the privacy and equality interests in personal records will be fought. ${ }^{142}$

A final matter of note is the level of deference extended by appellate courts to the production decisions of trial judges. Six appellate cases post-Mills have involved substantive decisions on production issues, and in four out of these six, lower court decisions were upheld on appeal. ${ }^{143}$ In several cases, the importance of deference was explicitly mentioned and was said to derive from the Supreme Court's decision in Mills. ${ }^{144}$ This deference arises from and reinforces the level of discretion in the trial judge, and suggests the initial decision on a production application is critical to whether the records will ultimately be produced.

Ibid. at paras. 61, 66. See also R. v. Kasook, [2001] 2 W.W.R. 683 (N.W.T. S.C.).

Ibid. at para. 33, citing Mills at para. 135 and $O^{\prime}$ Connor at para. 146. Although both cases refer to cross-examination of "Crown witnesses" generally, the Court of Appeal finds that this includes complainants.

Criminal Code, supra note 49, s. 278.4(2).

Dagenais, supra note 40; A.(L.L.), supra note 24; Criminal Code, ibid., s. 278.4(2).

Cross-examination is not a new battleground in sexual assault cases. See, e.g., Seaboyer, supra note 22 (concerning cross-examination on a complainant's past sexual history); $R$. v. Osolin, [1993] 4 S.C.R. 595 (concerning cross-examination on a complainant's medical records to determine whether there was evidence to support the defence of honest but mistaken belief in consent or an allegation of fabrication).

$R$ v. G.S., supra note $127 ; R$. v. P.E., supra note $127 ; R$. v. G.P.J., supra note $127 ; R$. v. E.A.N., supra note 127.

See R. v. G.S., ibid. at para. 13; R. v. G.P.J., ibid. at para. 16; R. v. E.A.N., ibid. at para. 16. 


\section{LOWER COURTS}

As noted, there is a relatively small number of lower court decisions post-Mills: 24 cases where substantive decisions were made on the question of production. ${ }^{145}$ For the purposes of analysis, the six appellate level cases involving production decisions will be added, for an overall sample of 30 cases.

Consistent with pre-Mills cases, a variety of records continues to be sought by the defence: child welfare records; ${ }^{146}$ social and community services records; ${ }^{147}$ counselling records; ${ }^{148}$ school and work records; ${ }^{149}$ medical and hospital records; ${ }^{150}$ alcohol treatment records; ${ }^{151}$ criminal injuries compensation records; ${ }^{152}$ and diaries. ${ }^{153}$ Counselling records were the subject of 16 out of 30 applications, and thus are still the most widely sought records in production applications. ${ }^{154}$ Moreover, many production applications are for multiple kinds of records rather than a focused request for a single document or even kind of document. ${ }^{155}$ The cases thus suggest

See $R$. v. D.H., [2000] A.J. 142 (Prov. Ct.), online: QL (AJ); R. v. M.G., supra note 131; $R$. v. M.A.S., [2000] M.J. 516 (Prov. Ct.), online: QL (MJ); R. v. W.C., [1999] M.J. 542 (Q.B.), online: QL (MJ); $R$ v. J.J.P., [2000] N.J. 156 (S.C.T.D.), online: QL. (NJ); $R$. v. Tatchell, [2001] N.J. 314 (S.C.T.D.), online: QL (NJ); R. v. W.G., [2000] N.J. 86 (S.C.T.D.), online: QL (NJ); R. v. D.P.F. (No. 3), [2001] N.J. 234 (S.C.T.D.), online: QL (NJ); R. v. C.S., [2000] N.J. 302 (S.C.T.D.), online: QL (NJ); R. v. W.P.N., [2000] N.W.T.J. 15 (S.C.), online: QL (NWTJ); R. v. K.A.G., [2001] N.S.J. 71 (Fam. Ct.), online: QL (NSJ); R. v. N.P., [2001] O.J. 1828 (Sup. Ct.), online: QL (OJ); R. v. S.P., [2001] O.J. 2898 (Sup. Ct.), online: QL (OJ); $R$. v. Thompson, supra note 131; $R$. v. D.M., supra note 131; R. v. Hudson, [2001] 0. . 5456 (Sup. Ct.), online: QL (OJ); $R$. v. R.W.K., [2000] O.J. 2847 (Sup. Ct.), online: QL (OJ); R. v. L.S., supra note 131; R. v. L.P.M., [2000] 0.J. 4076 (Sup. Ct.), online: QL (OJ); R. v. L.G., supra note 131; $R$. v. Leatherdale, [2000] O.J. 5105 (Sup. Ct.), online: QL (OJ); R. v. M.C., [2000] J.Q. 7022 (C.Q. (rib. jeun.)), online: QL (QJ); $R$. v. Joseph, [1999] J.Q. 6036 (C.Q. (trib. crim.)), online: QL (QJ); $R$ v. P.J.S., supra note 131 .

$R$ v. B.P., supra note 127 ; $R$. v. D.H., ibid.; $R$. v. M.G., supra note $131 ; R$. v. M.A.S., ibid; $R$. v. W.C., ibid.; R. v. N.P., ibid.; R. v. Hudson, ibid.; R. v. R.W.K., ibid.; R. v. L.P.M., ibid; R. v. M.C., ibid.

$R$. v. G.S., supra note $127 ; R$. v. J.J.P., supra note $145 ; R$. v. W.G., supra note $145 ; R$. v. Joseph, supra note 145.

Batte, supra note $127 ; R$. v. P.E., supra note $127 ; R$. v. G.P.J., supra note $127 ; R$. v. E.A.N., supra note $127 ; R$. v. D.H., supra note $145 ; R$. v. J.J.P., ibid.; $R$ v. W.G., ibid.; $R$. v. C.S., supra note $145 ; R$. v. W.P.N., supra note $145 ; R$. v. S.P., supra note $131 ; R$. v. Thompson, supra note 131; $R$. v. Hudson, supra note $145 ; R$. v. D.M., supra note $131 ; R$. v. L.G., supra note $131 ; R$. v. L.S., supra note $145 ; R$. v. R.W.K., supra note 145.

R. v. R.W.K., ibid.; R. v. Tatchell, supra note $145 ; R$. v. D.P.F., supra note $145 ; R$. v. K.A.G., supra note $145 ; R$. v. N.P., supra note 145.

R. v. P.E., supra note $127 ;$ R. v. J.J.P., supra note $145 ; R$. v. W.G., supra note $145 ;$ R. v. Hudson, supra note $145 ; R$ v. L.G., supra note $131 ; R$. v. Leatherdale, supra note $145 ; R$. v. R.W.K., supra note $145 ; R$. v. Joseph, supra note $145 ; R$. v. P.J.S., supra note 131. $R$ v. W.P.N., supra note 145.

152 R. v. L.S., supra note 131.

15. R. v. D.W.L., supra note 127 ; R. v. D.M., supra note 131 ; R. v. L.G., supra note $131 ;$ R. v. W.P.N., supra note 145. 145: $R$. v. D.M. supra note $131 ; R$. v. Hudson, supra note $145 ; R$. v. L.G., supra note $131 ; R$. v. 
that "fishing expeditions" continue to occur in many cases, and while perhaps fewer in number, production applications often do not differ in kind or motivation from those which occurred before Mills.

The grounds underlying production applications mirror those seen in pre-Mills cases: reliability and credibility of the complainant at large, and more specific allegations impugning reliability and credibility; the presence of prior inconsistent statements, motive to fabricate, collusion, false memory syndrome, or often, some combination of these. Competence of the complainant or witness to testify, while one of the recognized grounds of likely relevance, is rarely argued. ${ }^{156}$ In other cases, the reasons for decision are unclear about the grounds of relevance articulated by the defence. ${ }^{157}$

The extent to which the cases involve fact patterns where there is a prior relationship between the accused and complainant is another issue worthy of consideration. Consistent with Busby's research, most of the cases surveyed here involve either family members, ${ }^{158}$ or others known to the complainant, ${ }^{159}$ supporting the argument that the accused is not in a Catch-22 position regarding the requirement that he establish the likely relevance of records. Not all the cases provide this information about the factual context of the case, so the percentage of cases where the accused knew the complainant may be even higher. Also consistent with Busby's observations is the fact that very few of the cases indicate whether the complainant is from a racial minority, is disabled, or is otherwise disadvantaged, ${ }^{160}$ making it difficult to analyze the extent to which the courts engage in equality analysis that considers all aspects of a complainant's identity.

Of the 30 cases where a production decision was made, 14, or slightly less than half, involved decisions to produce at least some records to the court. ${ }^{161}$ Many decisions

L.S., supra note $131 ; R$ v. R.W.K., supra note $145 ; R$ v. Joseph, supra note 145.

For cases where likely relevance to competence was argued, see $R$. v. Tatchell, supra note 145 ;

$R$. v. Leatherdale, supra note $145 ; R$. v. Joseph, ibid.

137 R. v. Thompson, supra note $131 ; R$. v. W.C., supra note 145.

13* R. v. B.P., supra note 127 ; R. v. P.E., supra note $127 ; R$. v. G.P.J., supra note $127 ;$ R. v. E.A.N., supra note $127 ; R$ v. M.A.S., supra note $145 ; R$ v. N.P., supra note $145 ; R$. v. S.P., supra note $131 ; R$. v. $L . G$., supra note $145 ; R$. v. D.M., supra note $131 ; R$ v. $R$.W.K., supra note $145 ; R$. v. J.J.P., supra note $145 ; R$ v. W.G., supra note $145 ; R$. v. W.P.N., supra note $145 ; R$ v. M.C., supra note 145.

Batte, supra note $127 ;$ R. v. G.S., supra note $127 ; R$ v. K.A.G., supra note $145 ; R$. v. Hudson, supra note $145 ; R$. v. Leatherdale, supra note $145 ; R$. v. P.J.S., supra note 131 . In several other cases, it appears that the accused knew the complainant before the alleged sexual offence, although this is not explicit: R. v. L.S., supra note $131 ; R$. v. L.P.M., supra note $145 ; R$. v. M.G., supra note $131 ; R$. v. J.J.P., supra note $145 ; R$. v. C.S., supra note 145 .

Busby (2000), supra note 25 at 367-68. For an exception to this general rule, see Tatchell, supra note 145 , where the complainant's blindness and mild cognitive impairment were mentioned by the court. The latter was found to be a relevant consideration at para. 20: "It appears to me that this application may be based upon a discriminatory belief or bias that all persons with an intellectual disability, even when it is characterized as mild, are potentially incapable of telling the truth or are not competent to testify." supra note $145 ; R$ v. $L . G$., supra note $131 ; R$. v. Leatherdale, supra note $145 ; R$. v. L.S., supra note $131 ; R$ v. $R . W . K$, supra note $145 ; R$. v. L.P.M., supra note $145 ; R$. v. W.C., supra note 145 ; $R$ v. W.G. supra note $145 ; R$. v. C.S., supra note $145 ; R$. v. K.A.G., supra note $145 ; R$ v. W.P.N., 
do not make it clear whether the records ordered to be produced to the court were subsequently produced to the defence at the second stage of the application. In the nine cases where it is clear, records were produced to the defence, at least in part, in seven cases, ${ }^{162}$ and not produced to the defence in only two cases. ${ }^{163}$ While it is difficult to identify trends in such a small sample, it appears that where courts order production at the first stage, they are more likely to order production to the accused than not after reviewing the records. Defence counsel might suggest that this supports their Catch-22 argument - if only someone could see the records, this would reveal their likely relevance - but another explanation is that in cases where a judge finds that the factors play out in favour of production to the court, they will similarly find that the factors play out in favour of production to the accused.

The reasons provided by trial judges can be very unhelpful in terms of understanding the basis for the order to produce or not to produce records. Courts often just parrot the language of the production provisions, noting that they have taken all of the relevant factors into account without showing their actual reasoning. ${ }^{164}$ Arguably, this is a direct result of Mills and the Supreme Court's reassurance to trial judges that they need only take the factors into account "to the extent possible at this early stage of proceedings," and that they "are not required to rule conclusively on each of the factors," nor even balance them. ${ }^{165}$ This paucity of reasoning will present a challenge for appellate level courts, and may be another factor in the deference shown to decisions of trial judges. ${ }^{166}$

In several cases, courts have found that the defence had an insufficient evidentiary basis to establish likely relevance. ${ }^{167}$ Indeed, this seems to be one of the pre-eminent bases for disallowing production applications. Again, this trend flows from the Mills case and its holding that the grounds listed in s. 278.3(4) are permissible provided there is a sufficient evidentiary basis to support their relevance to an issue at trial or the competence of the witness to testify.

The comments of the majority in $O^{\prime}$ Connor on the relevance of "therapy which may have influenced the complainant's memory" continue to have their own influence on lower court decisions as an accepted basis of likely relevance. A sufficient evidentiary

supra note 145. This level of production is consistent with Busby's findings for cases decided under Bill C-46 prior to Mills.

R. v. G.P.J., ibid; $R$ v. Leatherdale, ibid,; R. v. L.P.M., ibid.; R. v. W.C., ibid.; R. v. W.G., ibid.;

R. v. C.S., ibid; R. v. K.A.G., ibid.

las

li.t See, e.g., R. v. G.P.J., supra note $127 ;$ R. v. W.C., supra note $145 ;$ R. v. K.A.G, supra note 145; $R$. v. Leatherdale, supra note 145.

ics Mills, supra note 11 at paras. $134,141$.

iks. In R. v. G.S., supra note 127, the Ontario Court of Appeal noted that the reasons of the trial judge were "conclusory with little analysis," but were nevertheless entitled to deference ([2001] $0 . J$. 1963 at para. 13, online: QL (OJ)).

167 Batle, supra note $127 ;$ R. v. P.E., supra note $127 ; R$. v. J.J.P., supra note $145 ; R$. v. W.P.N., supra note $145 ; R$ v. N.P., supra note $145 ; R$ v. D.M., supra note $131 ; R$. v. S.P., supra note $131 ; R$. $v$. Thompson, supra note $131 ; R$. v. Hudson, supra note $145 ; R$ v. $L . G$., supra note $131 ; R$. v. M.C., supra note $145 ; R$. v. Joseph, supra note $145 ; R$ v. M.G., supra note 131 ; $R$. v. M.A.S., supra note 145. 
basis to establish the likely relevance of records in this respect was found to exist in two cases. ${ }^{168}$ In other cases, the absence of any evidence of recovered memories, ${ }^{169}$ or of "illegal, improper, unethical or questionable practices or methods" of counselling ${ }^{170}$ was found to be relevant to the determination that the records in question should not be produced. The "insufficient ground" in s. 278.3(4)(f), "that the record may relate to the reliability of the testimony of the complainant or witness merely because the complainant or witness has received or is receiving psychiatric treatment, therapy or counselling," has thus proven to be insufficient to offset the majority decision in $O^{\prime}$ Connor in this area.

Another major turning point in production applications post-Mills is whether the courts find a reasonable expectation of privacy in the records in question. Cases have established that certain kinds of records have a high expectation of privacy: school records; ${ }^{171}$ diaries; $;{ }^{172}$ counselling records; ${ }^{173}$ child welfare records; $;{ }^{174}$ alcohol treatment records; ${ }^{175}$ hospital records; ${ }^{176}$ and records regarding the complainant's level of mental functioning. ${ }^{177}$ Personnel records have been found to have a moderate expectation of privacy - lower than for therapeutic records, but still "significant."178 Records found to have no reasonable expectation of privacy include those containing statements made to spark an investigation; ${ }^{179}$ criminal injuries compensation applications; ${ }^{180}$ records of a meeting where the accused was present with the complainant; ${ }^{181}$ a psychiatrist's report of meetings with complainants which was prepared for a dangerous offender hearing, ${ }^{182}$ and a group-home log relating to the timing of an incident relevant to a motive to fabricate. ${ }^{183}$ Coughlan has argued that this analysis, which was undertaken in Mills, is improper, as documents included within the scope of "record" in s. 278.1 of the Criminal Code have by definition a reasonable expectation of privacy. Thus it should not be necessary to determine whether "it is also independently true that there is a reasonable expectation of privacy"184 in such records, as this analysis is redundant and amounts to a reading down of Bill C-46.

R. v. C.S., supra note $145 ; R$. v. W.G., supra note 145.

See Batte, supra note 127 at para. $69 ;$ R. v. P.E., supra note 127 at para. $12 ;$ R. v. D.M., supra note 131 at para. $57 ; R$. v. W.P.N., supra note 145 at para. $14 ; R$. v. Thompson, supra note 131 at para. $9 ; R$ v. M.A.S., supra note 145 at para. 12.

$R$. v. J.J.P., supra note 145 at para. 21.

$R$. v. N.P., supra note 145.

R. v. D.M., supra note $131 ;$ R. v. D.W.L., supra note $127 ; R$. v. W.P.N., supra note 145.

R. v. D.M., ibid.

R. v. M.G., supra note $131 ; R$. v. M.C., supra note 145.

$R$ v. W.P.N., supra note 145 .

$R$ v. P.J.S., supra note 131 .

$R$. v. Tatchell, supra note 145.

$R$ v. D.P.F., supra note 145 , dealing with the personnel records of one of the investigating officers. See also [2000] N.J. 272 and [2001] N.J. 233, online: QL (NJ), for other applications involving production issues in the same case.

$R$. v. L.P.M., supra note $145 ; R$. v. K.A.G., supra note 145 .

$R$. v. L.S., supra note 131 .

R. v. B.P., supra note 127 .

R. v. D.P.F., supra note 145 (obiter).

$R$. v. Hudson, supra note 145 .

Coughlan, supra note 90 at 302 [emphasis in original]. 
Courts have also ruled on the other factors related to whether production will be ordered on balance. In several cases, courts have refused production where it would be prejudicial to the complainant's dignity, privacy, or equality interests. ${ }^{185}$ Production was also refused in two cases where it was found that it would be contrary to society's interests in encouraging the reporting of sexual offences. ${ }^{186}$ On the other hand, lower courts have followed Mills in holding that the rights of the accused must prevail where the court is in doubt whether to order production. ${ }^{187}$

Procedural aspects of the production provisions have also been judicially considered. On the question of waiver, lower courts have held that consent to release some records by a complainant does not amount to a waiver for all records, nor is consent to release records by one complainant relevant with respect to the records of another complainant in the same case. ${ }^{188}$ Moreover, turning over records to the Crown does not amount to a waiver where the complainant was not fully informed of the consequences, ${ }^{189}$ or where her young age precluded her from understanding the consequences. ${ }^{190}$ In a case with multiple complainants, a court has found that one complainant is not compellable to give evidence in relation to the records of another complainant, but that a complainant's spouse is a compellable witness in a production hearing. ${ }^{191}$ While procedural compliance with the production provisions is one of the criteria which must be satisfied before a judge may order production, ${ }^{192}$ a trial judge is obliged to provide reasonable assistance to an unrepresented accused concerning the production procedures, and failure to do so may form a successful ground of appeal. ${ }^{193}$

Another trend to be examined is whether complainants and record holders are being represented by counsel in production applications. The importance of representation for these parties cannot be overstated, as Crown counsel are simply not in a position to represent the equality and privacy interests of complainants and record holders. ${ }^{194}$

R. v. Tatchell, supra note $145 ; R$. v. W.P.N., supra note $145 ; R$. v. D.M., supra note $131 ; R$ v. Joseph, supra note $145 ; R$. v. P.J.S., supra note 131.

18, R. v. D.M., ibid; R. v. Tatchell, ibid. See R. v. R.W.K., supra note 145 for a contrary decision.

187 See R. v. L.P.M., supra note $145 ;$ R. v. R.W.K., ibid.; R. v. L.G., supra note 131.

Iss R. v. L.S., [2000] O.J. 3991 (Sup. Ct.), online: QL (OJ).

$189 R$ v. W.P.N., [2000] N.W.T.J. 15 (S.C.), online: QL (NWTJ).

R. v. D.P.F. (No. I), [2000] N.J. 272 (S.C.T.D.) at paras. 34-37, online: QL (NJ).

R. v. D.P.F. (No. 2), [2001] N.J. 233 (S.C.T.D.), online: QL (NJ).

Criminal Code, supra note 49, s. 278.5(1)(a). For a decision where procedural non-compliance (lack of service of production application on record holder) was fatal, see R. v. P.P., [2001] M.J. 438 (Prov. Ct.), online: QL (MJ). At the same time, the court in this case abridged the time for the service of a production application on the complainant, as her counsel was aware of the application ahead of time (at para. 15). On the other hand, it has been said that where a delay in trial may occur as a result of a production application, improper service by the accused "could preempt the hearing." See $R$. v. M.G., [2001] M.J. 61 (Prov. Ct.) at 3 (obiter), online: QL (MJ). $R$ v. B.P., [2000] O.J. 3852 (C.A.), online: QL (OJ). A new trial was ordered in this case.

194 As a former prosecutor, I can attest to the fact that the practical demands upon the Crown prevent this actor from being the guardian of complainants' and record holders' interests. Of course, so does the law. See Boucher v. The Queen, [1955] S.C.R. 16 at 23-24. For cases where this is apparent, see $R$. v. D.H., supra note 145 , where the Crown consented to releasing several records to the court where the complainant and record holders were not represented, and $R$. v. L.S., supra note 131 , where the Crown disclosed to the defence that one of the complainants had received counselling, and that both complainants had made applications to the Criminal Injuries 
However, this survey of post-Mills production applications shows that complainants were represented by counsel in only 13 of the 24 lower court cases, ${ }^{195}$ and record holders were represented in only $11 .{ }^{196}$ Why are complainants and record holders not routinely represented by counsel? One possible response is that they may not always seek to participate in production applications. For record holders, however, it likely goes deeper than that. While complainants are eligible for state-funded counsel for production applications, record holders are generally not. ${ }^{197}$ This is an access to justice issue, and negatively affects the ability of record holders such as sexual assault centres to do the work for which they were created. In this sense, they are in a Catch22 of their own: either expend their scarce resources on fighting production applications at the expense of their other work, or allow production applications to go on without them.

\section{Other Production Issues}

Another vexing issue in the production context has been that of lost or missing records. This issue is an important one, as one would expect it to arise frequently in cases where the prosecution has been delayed, such as historic sexual assault cases. In $R$. v. Carosella ${ }^{198}$ a pre-Mills case, a sexual assault crisis centre had destroyed notes of its interview with a complainant before being issued with a subpoena to produce these notes at trial. A majority of the Supreme Court of Canada found that the destruction of records was fatal to the prosecution of the case. According to the majority, the complainant had consented to providing the notes to the Crown at the time of the interview, so the notes would have been subject to disclosure to the defence according to Stinchcombe. Even if the "somewhat higher" standard from $O^{\prime}$ Connor had applied, the majority found that "the balancing required in the second stage of the test would have inevitably resulted in an order to produce; confidentiality had been waived and the complainant and the Crown consented to production." 199

The issue of lost evidence also arose in Stinchcombe the second time the case went to trial. In 1992, the Alberta Court of Queen's Bench issued a stay of proceedings on the basis that the tape recording of a police interview with Stinchcombe's former secretary, and her original handwritten statement, were lost. This stay of proceedings was overturned by the Court of Appeal, a decision upheld by the Supreme Court in

Compensation Board.

R. v. N.P., supra note $145 ; R$. v. D.M., supra note $131 ; R$. v. Hudson, supra note $145 ;$ R. v. L.G., supra note $131 ; R$. v. L.S., supra note $131 ; R$. v. L.P.M., supra note $145 ; R$. v. M.G., supra note $131 ; R$ v. M.A.S., supra note $145 ; R$ v. W.C., supra note $145 ; R$ v. Tatchell, supra note $145 ; R$. v. D.P.F. (No. 3), supra note $145 ; R$. v. W.G., supra note $145 ; R$. v. C.S., supra note 145.

R. v. N.P., ibid.; R. v. D.M., ibid.; R. v. Hudson, ibid; R. v. L.G., ibid.; R. v. L.P.M., ibid; R. v. M.G., ibid; R. v. M.A.S., ibid.; R. v. W.C., ibid.; R. v. Tatchell, ibid.; R. v. D.P.F. (No. 3), ibid.; $R$ v. W.P.N., supra note 145 .

Some provinces, such as B.C., have a system of funded representation for record holders, but this is exceptional and fragile given current funding cuts to legal aid. of the alleged incidents in 1964, and the accused was her teacher. 
1995. ${ }^{200}$ At face value, the difference between the two cases is that in Stinchcombe the Crown had disclosed a copy of the statement and a transcript of the taped interview, thus the material was available to the defence in some form. The substantive content of the impugned material was not available in Carosella, as the counsellor had no recollection of the contents of the destroyed notes. Moreover, in Carosella the destruction of records was intentional, while in Stinchcombe the records were simply lost. ${ }^{201}$ As noted by Christine Boyle, however, "[a]nother perspective ... is that the Centre engaged in the prudent destruction of irrelevant material which could only be used to discourage complainants in general ... and distort the trial process."202

Despite, or perhaps because of its difference from Stinchcombe (No. 2), Carosella raises some troubling issues. In Carosella, the majority of the Supreme Court accepted the trial judge's ruling that the notes were relevant and material to the defence, notwithstanding that this was based on speculation as to the contents of the notes: they "might have been able to shed light on the 'unfolding of events,' or might have contained information bearing on the complainant's credibility [including] ... inconsistencies upon which the complainant could be cross-examined." ${ }^{203}$ Moreover, the majority placed a burden on third-party record holders normally reserved for the Crown. Even accepting the majority's conclusion that access to third-party records is a constitutional right, which is arguably an extension of $O^{\prime}$ Connor and Stinchcombe, this right could only bind the Crown, not third parties to whom the Charter does not apply. This was recognized by the four dissenting justices in the case. Justice L'Heureux-Dubé, along with La Forest, Gonthier and McLachlin JJ., were of the view that the case was not one about production; rather it should be viewed as a case of lost evidence. For the dissenting justices, missing evidence would contravene the accused's rights only where the defence could "demonstrate that a fair trial, and not a perfect one, cannot be had as a result of the loss." ${ }^{204}$ In contrast, the majority of the Court focused on the "image of the administration of justice," which in its view was sullied by "the destruction of documents ... by an agency that not only receives public money but whose activities are scrutinized by the provincial government." 205

As noted by the dissenting justices, the majority decision in Carosella is contrary to other decisions of the Supreme Court outside the sexual assault context, where the accused has had to show prejudice flowing from lost evidence, even where it was relevant. ${ }^{206}$ It is also contrary to appellate level decisions in the sexual assault context

R. v. Stinchcombe (No. 2) (1994), 149 A.R. 167 (C.A.), aff d [1995] I S.C.R. 754.

In Stinchcombe, the Court was persuaded by the fact there was no misconduct on the part of the Crown. See ibid. at para. 1.

Boyle, supra note 96 at 90 .

Carosella, supra note 198 at para. 44 [emphasis added].

Ibid. at para. 74. The dissenting justices held, at para. 112, that the notes would not have met the test of likely relevance from $O^{\prime}$ Connor, so there was no compromise to the accused's right to a fair trial.

lbid. at para. 56.

Jbid. at para. 79-80, citing $R$ v. Finta, [1994]-1 S.C.R. 701. 
dealing with lost evidence, ${ }^{207}$ and to American jurisprudence, which requires prejudice to the accused and often, bad faith on the part of the state for a stay of proceedings. ${ }^{208}$ The requirement of prejudice was reaffirmed by the Supreme Court in a case decided the same year as Carosella, R. v. $L a .^{209}$

While Mills did not deal with the issue of missing records, it and subsequent cases suggest the records sought in Carosella would no longer meet the test for production in the Criminal Code. In a recent case where it was found that a destroyed diary would not be producible, the Nova Scotia Court of Appeal overturned a stay of proceedings. ${ }^{210}$ In another case, even where the records would have met the test for production, a stay was found to be inappropriate where the records were not deliberately destroyed to frustrate production, and neither the police nor Crown were involved in the destruction. ${ }^{211}$ Thus it appears that Carosella is being restricted to situations where the destroyed records would be producible, and the destruction was deliberate and implicated the state. This is certainly a positive development for record holders, and adds some certainty to their ability to deal with records prior to trial.

Another issue to be explored is the extent to which production applications are occurring outside the sexual assault context. According to s. 278.2(1) of the Criminal Code, the production provisions only apply to cases where the accused has been charged with sexual offences. Lower court decisions confirm that $O^{\prime} C o n n o r$ continues to apply to other cases where third-party records are sought, including cases involving other forms of violence. ${ }^{212}$ One exception has been carved out by the courts: where other charges arise in addition to a sexual offence in the same set of circumstances, the courts have ruled that the production provisions should apply to records sought in relation to all the charges. ${ }^{213}$ Outside of this exception, the application of Batte will be a matter to watch, given its narrowing of the definition of likely relevance in the context of an $O^{\prime}$ Connor application.

It could be argued that applications for records in other cases involving violence against women and children should be governed by the production provisions, given that myths and stereotypes relating to relevance may similarly underlie these

See, e.g., $R$ v. Dieffenbaugh (1993), 80 C.C.C. (3d) 97 (B.C. C.A.), as cited in Carosella, ibid. at para. 77. For a more recent decision denying a stay of proceedings where evidence was lost in a sexual assault case, see $R$. v. Bradford, [2001] O.J. 107 (C.A.), online: QL (OJ), leave to appeal to S.C.C. denied [2001] S.C.C.A. No. 131 . Carosella, ibid. at para. 85.

[1997] 2 S.C.R. 680. Like Carosella, $R$ v. La was a case of sexual violence, although the Court at para. 26 distinguished Carosella on the basis that it involved records which were relevant, and had been deliberately destroyed.

R. v. D.W.L., [2001] N.S.J. 269 (C.A.), online: QL (NSJ).

$R$ v. $R$.W.K., [2000] O.J. 2847 (Sup. Ct.) at para. 22-23, online: QL (OJ), involving school records.

See, e.g., R. v. Hunter (2000), 268 A.R. 90, [2000] A.J. 747 (Prov. Ct.), online: QL (AJ) (assault with a weapon); R. v. E.R., [2000] O.J. 5083 (C.J.), online: QL (OJ) (wife assault).

$R$ v. N.P., [2001] O.J. 1828 (Sup. Ct.), online: QL (OJ). 
applications. ${ }^{214}$ This would likely require legislative change, although it could be argued that Bill C-46, constitutionally approved in Mills, should apply in an interpretive sense. For example, the factors rejected in $O^{\prime}$ Connor - women's equality interests, and the impact of production on counselling and reporting - could be argued to be relevant to production applications outside the sexual assault context given their approval in Mills.

\section{Conclusion}

As noted in the introduction, a full account of the law of disclosure and production must analyze the ways in which these strategies have been used in the sexual assault context in particular ways, in relation to particular records, to reinforce particular myths. While Bill C-46 and Mills are positive developments in some respects, much discretion is left to trial judges to decide the merits of producing personal records on a case-by-case basis, and the decisions of lower courts are granted much deference by appellate courts. Discretion leaves this terrain open to the application of myths and stereotypes about women, children, and sexual violence, which is why a "no records, any time" position would have been preferred by many women's and anti-violence groups.

Several issues remain that will likely wind their way through the courts and, perhaps, legislatures. To what extent can complainants be cross-examined at preliminary inquiries on the scope and contents of their records as a precursor to production applications? Should the production provisions be extended to apply to other offences involving violence against women and children? Will applications for production be replaced by a new defence strategy in sexual assault cases? These are important questions, and it is hoped that Parliament and the courts will continue to allow a broad range of voices to inform this conversation.

For example, in R. v. Lavallee, [1990] I S.C.R. 852, the Supreme Court of Canada set out some of the myths that may exist in the case of battered women at 889: "It is commonly thought that battered women are not really beaten as badly as they claim, otherwise they would have left the relationship. Alternatively, some believe that women enjoy being beaten, that they have a masochist strain in them." In a later case, $R$. v. Malott, [1998] I S.C.R 123 at para. 40, the Court recognized that a new stereotype of a "victimized, passive, helpless, dependent, battered woman" was also to be avoided. These myths could clearly influence defence arguments about the likely relevance of records in cases of intimate violence. 